Cansoy, R. \& Polatcam, M. (2019). The Relationship Between School Principals' Leadership and Teachers' Organisational Commitment: A Systematic Review. Bartın University Journal of Faculty of Education, 8(1), 1-31.

Bartın University Journal of Faculty of Education, 8(1), 1-31

Bartın Üniversitesi Eğitim Fakültesi Dergisi, 8(1), 1-31

buefad.bartin.edu.tr

\title{
The Relationship Between School Principals' Leadership and Teachers' Organisational Commitment: A Systematic Review
}

\author{
Ramazan CANSOYa, Mahmut POLATCAN*b
}

\begin{tabular}{|c|c|c|}
\hline \multicolumn{2}{|c|}{ Article Info } & Abstract \\
\hline \multicolumn{2}{|c|}{ DOI: 10.14686/buefad.441189 } & $\begin{array}{l}\text { The aim of this study is to conduct a systematic review of studies on the relationship } \\
\text { between school principals' leadership behaviors and teachers' organizational }\end{array}$ \\
\hline \multicolumn{2}{|c|}{ Article History: } & commitment. For this purpose, 23 research articles indexed in WOS, ERIC, EBSCO, \\
\hline Received & 05.07.2018 & SCOPUS and ULAKBİM databases between 2000-2017 in the Turkish context and \\
\hline Accepted & 22.10 .2018 & selected through certain criteria were collected for analysis. According to the results \\
\hline Publishe & 01.02.2019 & of the studies examined, as the leadership behaviours that were prominent in these \\
\hline \multicolumn{2}{|c|}{$\begin{array}{l}\text { Keywords: } \\
\text { Organizational commitment, } \\
\text { Leadershp behaviour, } \\
\text { Systematic review. }\end{array}$} & $\begin{array}{l}\text { studies were having a common objective and vision in school, forming a culture of } \\
\text { cooperation, enhancing communication and interaction, showing interest and } \\
\text { appreciation of individuals, supportive and constructive behaviours, being fair, } \\
\text { creating a working culture based on respect and trust, sharing responsibilities, and }\end{array}$ \\
\hline \multicolumn{2}{|c|}{$\begin{array}{l}\text { Article Type: } \\
\text { Review }\end{array}$} & $\begin{array}{l}\text { principals' organizational commitment was reported to be positively related to } \\
\text { transformational leadership, servant leadership, and ethical leadership behaviors. } \\
\text { These leadership behaviors were also found to be important predictors of } \\
\text { organizational commitment. }\end{array}$ \\
\hline
\end{tabular}

\section{Okul Müdürü Liderliği ve Öğretmen Bağlılığı İliş̧kisi: Sistematik Bir} Derleme

\begin{tabular}{|c|c|}
\hline Makale Bilgisi & Öz \\
\hline DOI: $10.14686 /$ buefad.441189 & \multirow{7}{*}{ 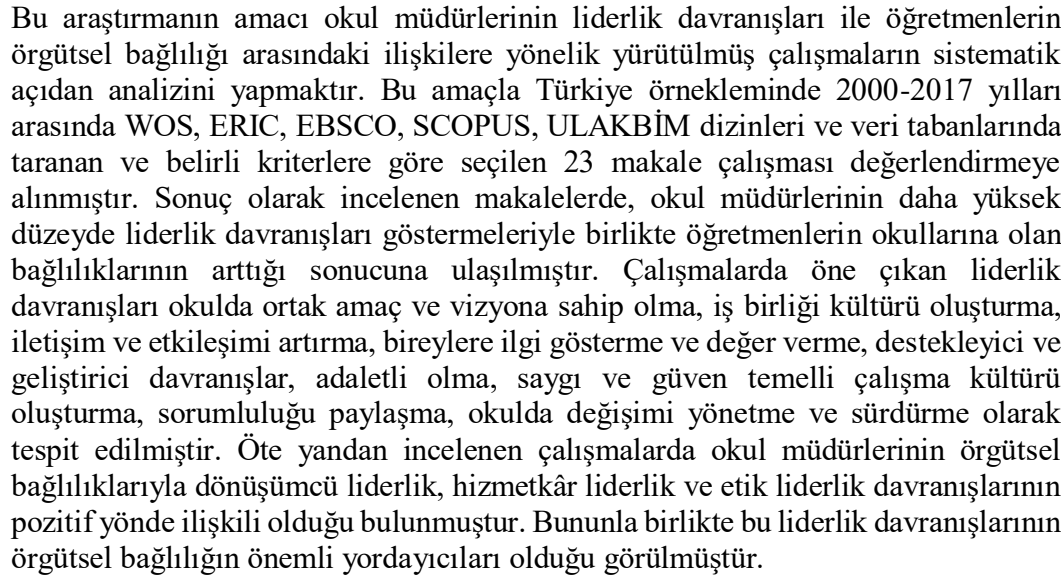 } \\
\hline Makale Geçmişi: & \\
\hline 05.07.2018 & \\
\hline 22.10 .2018 & \\
\hline 01.02 .2019 & \\
\hline $\begin{array}{l}\text { Anahtar Kelimeler: } \\
\text { Örgütsel bağlılık, } \\
\text { Liderlik davranışı, } \\
\text { Sistematik derleme. }\end{array}$ & \\
\hline $\begin{array}{l}\text { Makale Türü: } \\
\text { Derleme }\end{array}$ & \\
\hline
\end{tabular}

\footnotetext{
*Corresponding Author: mahmutpolatcan78@ gmail.com

${ }^{a}$ Asst. Prof. Dr., Karabuk University, Karabuk/Turkey, https://orcid.org/0000-0003-2768-9939

${ }^{\mathrm{b}}$ Dr., Karabuk University, Karabuk/Turkey, https://orcid.org/0000-0002-5181-0316
} 


\section{Introduction}

School principals' leadership has been an important research area in education for about 50 years (Waters \& Marzano, 2006). Particularly at elementary and high school levels, effective school and principal leadership have been researched for sustainable achievement and instructional development (Heck \& Hallinger, 1996; Spillane, 2003). In this respect, researchers state that initial research on school leadership emphasized student achievement and teacher performance (Leithwood \& Jantzi, 2005; Murphy \& Vriesenga, 2006; Yukl, 2012). As for recent leadership studies in the field of school management, they mostly focused on leadership styles. Many researchers think that leadership style is a significant variable that affects how members of an organization work. They thus reported that school principals' leadership styles (transformational, interactional, operational, distributive and instructional) affected employees' perceived job satisfaction, performance, school culture and climate and their behaviours of organisational citizenship, organisational justice, school participation and school development (Blase \& Blase, 1999; Dinham, 2005; Griffith, 2004; Harris, 2004; Heck, Larsen \& Marcoulides, 1990; Leithwood \& Jantzi,1990; Marks \& Printy, 2003; Nguni, Sleegers \& Denessen, 2006; Silins, 1994). Day and Leithwood (2007) state that the findings of studies on the importance of leadership in schools are satisfactory. Furthermore, teacher commitment, which is one of the primary concepts focused in the present study, was demonstrated to be affected by school principals' leadership behaviors (Geijsel, Sleegers, Leithwood \& Jantzi, 2003; Ross \& Gray, 2006).

Comprehensive studies on organizational commitment were conducted in the literature (Buchanan, 1974; Kim, Eisenberger ve Baik, 2016; Gupta, 2017; Mathieu \& Zajac, 1990; Mathieu \& Farr, 1991; Meyer, \& Allen, 1991; Mowday, Steers \& Porter, 1979; O’Reilly \& Chatman, 1986; Steers, 1977; Yahaya \& Ebrahim, 2016). Organisational commitment is known as a positive concept. It is accepted as an important variable in understanding employees' behaviors towards the job in organizations (Meyer, Stanley, Herscovitch \& Topolnytsky, 2002; Mowday, Steers \& Porter, 1979). Moreover, teachers' organizational commitment plays a significant role in achieving reforms and success in education in general and enhancing individual performance in particular (Tsui \& Cheng, 1999). In this respect, many studies carried out in school contexts showed that teachers' organizational commitment was a significant predictor of their job performance, absenteeism and quitting work (Cheng, 1990; Morris \& Sherman, 1981; Mowday, Porter \& Steers, 1979). Besides, some studies also reported positive relationships between teachers' motivation, job satisfaction, self-efficacy and commitment (Canrinus, Helms-Lorenz, Beijaard, Buitink \& Hofman, 2012; Rosenholtz, 1989).

Determining the tendencies of the studies that examine the relationships between school principals' leadership styles and teachers' organizational commitment is of significance. Therefore, the aim of this systematic review is to analyze research articles that focus on the relationships between school principals' leadership styles (e.g. transformational, operational, instructional and distributive) and teachers' organizational commitment.

\section{Theoretical Background}

Creating a positive learning environment and setting norms for the working environment depends on effective school principals (Hallinger, Bickman \& Davis, 1996). Differences among schools such as taking an active role in instructional practices, ensuring communication among staff members, increasing employees' motivation, commitment, and job satisfaction, forming a positive school environment and contributing to student achievement are attributed to school principals' leadership (Andrews \& Soder, 1987). Accordingly, school principals as leaders are defined as individuals who build a trust-based relationship with school staff, improve teachers' knowledge and skills and contribute to school achievement (Youngs \& King, 2002). In other words, they are the individuals who take on various roles in schools, work with others to guide their followers and influence them to achieve the school goals (Leithwood \& Riehl, 2003). However, school administrators are expected to exhibit different leadership styles depending on developments in the field of education. There are many leadership styles such as transformational leaders who construct a vision and mission in school and increase their employees' motivation (Bass, 1990), instructional leaders who enhance the interaction between the curriculum and employees to boost achievement (Blase \& Blase, 1999), distributive leaders who ensure cooperation between professional learning communities and include their followers in decision-making processes (Heck \& Hallinger, 2009), servant leaders who work for the good of their followers without expecting anything in return (Black, 2010) and ethical leaders who set rules for interpersonal communication, make decisions and share them with their followers (Brown, Trevino \& Harrison, 2005). 
Teachers' organizational commitment, which is another variable of the present work, is an important factor for their job satisfaction, performance, and motivation as well as the effective functioning of schools. Teachers' commitment reflects their desire to meet their personal needs and work for the school (Anderman, Belzer \& Smith, 1991). In addition, teachers' perceptions of commitment develop the feeling of participation in important decisions for the school (Hart \& Willower, 1994). Organisational commitment, a topic that falls within organisational behaviour and psychology (Mathieu \& Zazac, 1990; Reichers, 1985), is individuals' becoming a part of the organisation, making effort for their belief in its goals and values, and their desire to continue being a member of the organisation (Porter, Steers, Mowday \& Boulian, 1974). In another definition, it is the individuals' feeling of commitment to an organization or group (O'Reilly \& Chatman, 1986). To sum up, as Cook and Wall (1980) state, organizational commitment refers to individuals' emotional reactions towards the organization's goals and values.

In the literature, there are different classifications related to the dimensions of organizational commitment. O'Reilly and Chatman (1986) consider the dimensions of commitment in three groups that are compliance, identification, and internalization. Modway et al. (1979) classify the concept as behavioral and attitudinal commitment, whereas Weiner (1982) categorie it as instrumental and moral commitment. Yet, in the educational literature, Meyer and Allen's dimensions are widely used in empirical studies. These scholars indicate three dimensions of organizational commitment that are affective, continuance and normative. Affective dimension is employees' feelings related to their adoption of organizational values, goals, and objectives. Continuance dimension is employees' enforcement towards the time and efforts they spare for their organization, and in return for this, their feeling that they are obliged to stay in the organization. This is because employees with compliance commitment think that they are less likely to find a new job if they leave their organization. Lastly, in normative commitment, employees think that working in the organization is a duty for them and the organization needs them in real terms, and bear the feeling of appreciation towards their employers (Allen \& Meyer, 1993; Meyer \& Allen, 2000;).

In the international literature, there are many studies on the relationship between school principals' leadership styles and teachers' organizational commitment (Anderman, 1991; Hallinger, Hosseingholizadeh, Hashemi \& Kouhsari, 2018; Hulpia, Devos \& Van Keer, 2011; Ibrahim, Ghavifekr, Ling, Siraj \& Azeez, 2014; Ross \& Gray, 2006; Sun, 2004; Yu, Leithwood \& Jantzi, 2002). Similar studies also exist in the Turkish context where school principals' leadership styles (Akan, 2015; Bektaş, Çoğaltay \& Sökmen, 2014; Buluç, 2009), charismatic characteristics (Arabac1, 2014), ethical leadership behaviours (Ayık, Yücel \& Savaş, 2014; Madenoğlu, Uysal, Sarıer \& Banoğlu, 2014; Okçu, 2014; Uğurlu, Sancar \& Çınar, 2013), spiritual leadership (Bozkuş \& Gündüz, 2016), servant leadership (Cerit, 2010; Doğan \& Aslan, 2016), transformational leadership (Çetin \& Aydın, 2012), and supportive and developer leadership (Erdoğan ve Kolamaz, 2011) were examined with relation to teachers' commitment.

The direction and level of the relationships between school principals' leadership behaviors and teachers' commitment and the relationships between the dimensions of organizational commitment and leadership styles should be examined in detail. Additionally, focusing on the relational findings reported in research studies as a whole is thought to contribute to the theoretical literature. Besides, common findings that are retrieved are assumed to guide further studies in this area of research. On the other hand, such findings will provide important data for leader school principals as practitioners regarding what leadership style(s) to exhibit in order to enhance teachers' commitment to the school. In this regard, the research question of the present study is as follows: "What are the common findings of the studies that examined the relationships between school principals' leadership styles and teachers' organizational commitment?"

\section{Method}

This study aimed at systematically reviewing the research studies that examined the relationships between school principals' leadership behaviors and teachers' organizational commitment in Turkey. In systematic reviews, findings of a research topic are selected and synthesized progressively based on certain criteria (Victor, 2008). It requires making choices related to a research topic after implementing the criteria, and holistically evaluate the pieces of proof. A set of systematic steps are followed for an objective review (Higgins \& Green, 2011). These steps include setting objectives, determining the scope, using certain inclusion criteria, data gathering methods and gathering the data (Lunny, Brennan, McDonald \& McKenzie, 2016). In this respect, systematic reviews consist of sections that are search strategy, inclusion criteria, scanning, gathering and defining the data, demonstrating the 
quality of the studies included, and synthesis of the findings, respectively (EPPI-Centre, 2006; Gough, 2007; Davies, Morriss \& Glazebrook, 2014; Germain \& Cummings, 2010; Karaçam, 2013).

\section{Inclusion Criteria}

In the present review, the criteria used to include research articles for analysis were period of publication (i.e. being published between 2000-2017), design and method (i.e. empirical and quantitative), type of journal (i.e. national and international refereed journal), and context (i.e. being conducted in educational institutions other than universities). Additionally, they should have been conducted in the Turkish context and reported teacher perceptions, and should have been indexed in respectable databases. Lastly, theses/dissertations and theoretical papers were excluded from the review.

\section{Search Strategy and Databases}

The data were gathered through systematic review with the help of the databases including WOS, ERIC, EBSCO, SCOPUS, and ULAKBIM. Google Scholar was additionally used when needed. In this process, the studies conducted in the Turkish context were searched with the following key terms: "organizational commitment, the relationship between, organizational commitment and leadership". In some cases, journal web sites were used for the search. These searches were done in both Turkish and English.

\section{Scanning}

A total of 197 articles were retrieved by searching the keywords "organizational commitment", "the relationship between, organizational commitment and leadership" in the databases. Forty-three articles were found in SCOPUS, while 50 in ULAKBIM, 40 in ERIC and 58 in Web of Science. The abstracts of the articles were read carefully. Theoretical, qualitative and recurring studies as well as those that are unrelated were excluded, which left 29 articles. However, these 29 articles were re-examined, and six of them were further excluded due to not being clear about sampling, method or content, or because of certain methodological problems. Thus, the review was conducted with 23 research articles.

\section{Determining the Quality of the Studies}

The quality of the 23 articles was evaluated based on EPPI-Centre (2006), and the framework for assessing the weight of evidence proposed by Gough (2007) and Davies et al. (2014). Evaluating the methodological quality, methodological relevance and topic relevance of studies as a whole demonstrate the weight of evidence. Therefore, being well-designed and employing reliable and valid measurement tools make studies stronger in terms of evidence. Besides, the methodology and the topic of the articles being relevant also contribute to this aspect. Both researchers of the present study prepared a quality check-list and evaluated the articles by rating them from 1 to 4 based on quality. In case of a disagreement, the opinion of an expert was obtained. The purpose was to present strong and weak evidence together in a certain order and make this attempt more reliable. In this step, the 23 articles examined was found to not to be insufficient in terms of quality. Then, in order to see the findings more clearly, the authors, topics, methods, measurement tools and findings of these studies are presented in a table (Appendix 1). The reliability coefficients of the instruments used in the studies ranged between .65 and .99. Most of the studies re-examined reliability in their own samples. In 18 studies, reliability coefficients were re-calculated, they were not reported in three studies, the coefficients of the original developers were given in two studies, and no reliability was reported in one study. In the studies in which coefficients were not reported, the methodology sections were evaluated as a whole and were not included in the analysis. The samples sizes ranged from 200 to 1112 individuals in the studies.

\section{Synthesis of the Findings}

In this phase, the articles were read, coded and summarised individually, and relevant themes were formed. Matrices were created with regard to the leadership behaviors related to organizational commitment. In these matrices, the dimensions that relate to organizational commitment were determined one by one, and themes were formed. Based on these relationships and themes, Table 1 was compiled which shows the relationships, and then Table 2 was obtained which shows the leadership behaviors that are related to organizational commitment. A list of the articles that were examined presented at the end of this paper. 


\section{Findings}

\section{Leadership Behaviours and Organisational Commitment}

In this section, the findings regarding the relationships between school principals' different leadership behaviors and organizational commitment are presented. The relationships in-between are firstly given in Table 1 . The relationships between the sub-dimensions of organizational commitment and leadership practices are then examined to reveal what characteristics of organizational commitment are related to leadership practices.

\section{Relationships between leadership behaviors and organizational commitment}

Five studies reported that transformational leadership was related to organizational commitment (Akan \& Yalçın, 2015; Bektaş, Çoğaltay \& Sökmen, 2014; Buluç, 2009; Çetin \& Aydın, 2012; Kul \& Güçlü, 2010). In two of these studies, transformational leadership was demonstrated to be a predictor of organizational commitment (Kul \& Güçlü, 2010; Bektaş, Çoğaltay \& Sökmen, 2014). In three studies, transformational leadership was found to be positively related to two organizational commitment dimensions, which are the identification and internalization (Akan \& Yalçın, 2015; Bektaş, Çoğaltay \& Sökmen, 2014; Buluç, 2009; Çetin \& Aydın, 2012; Kul \& Güçlü, 2010;). Bektaş, Çoğaltay, and Sökmen (2014) stated that among transformational, operational and laissez-faire leadership, transformational leadership had the highest explanatory power for explaining organizational commitment with 54\%, which was followed by operational leadership with $15 \%$ and laissez-faire leadership with $1 \%$. Kul and Güçlü (2010) reported that transformational leadership, but not operational leadership, predicted organizational commitment, while Akan and Yalçın (2015) found that identification commitment was negatively related to operational leadership. Buluç (2009) revealed that there were positive relationships between transformational leadership characteristics and organizational commitment, and one of these characteristics, inspirational motivation, was the only significant predictor of organizational commitment. In their study, Çetin and Aydın (2012) asserted that intellectual stimulation, a transformational leadership characteristic, predicted affective commitment, and was positively related to continuance commitment. In another study, Arabac1, Alaoğlu, and Doğan (2014) indicated that the charismatic leadership characteristics including determining a vision, showing environmental sensitivity, taking personal risks and maintaining communication were positively related to organizational commitment. Lastly, Buluç (2009) demonstrated that idealized effect and individual interest had a positive and significant relationship with organisational commitment.

Regarding the relationshpi between ethical leadership and organisational commitment, there are five studies conducted in the literature. Four of these studies found that ethical leadership was a significant predictor of organisational commitment (Ayık, Yücel \& Savaş, 2014; Madenoğlu, Uysal, Sarıer \& Banoğlu, 2014; Uğurlu, Sincar \& Çınar, 2013; Uğurlu \& Üstüner, 2011), while the fifth study reported a significant and positive relationship (Okçu, 2014). In these studies, the explanatory power of ethical leadership for explaining the variation in organisational commitment was reported as 14\% in Uğurlu and Üstüner (2011) and 6\% in Uğurlu, Sincar, and Çınar (2013), whereas Madenoğlu, Uysal, Sarıer, and Banoğlu (2014) stated that it had a high level of predictive power $(\beta=.74)$. As for the subdimensions of leadership, Uğurlu and Üstüner (2011) found that only climatic ethics, an ethical leadership behavior, was a significant predictor of teachers' commitment to the school. Okçu (2014) revealed that only the responsibility dimension, an ethical leadership behavior, predicted identification commitment, and the tolerance dimension predicted the internalization commitment. Ayık, Yücel, and Savaş (2014) stated that administrators' ethical behaviors were strong predictors of continuance and affective commitment, and were positively and significantly related to normative commitment. Besides, they also reported that ethics predicted continuance and normative commitment in decision-making. Similarly, Uğurlu, Sincar, and Çınar (2013) found that ethical leadership significantly predicted affective and normative commitment.

Two studies found that school principals' shared leadership behaviors positively predicted teachers' organizational commitment. In both studies, shared leadership had a positive relationship with the affective and normative commitment of teachers (Uslu \& Beycioğlu, 2013; Yetim, 2016). Uslu and Beycioğlu (2013) found that shared leadership behaviors were positively and significantly related to teachers' affective and normative commitment. While they stated that shared leadership behaviors explained $27 \%$ of the variation in organizational commitment, Yetim (2016) showed that shared leadership and organizational commitment had a significant and positive relationship.

There are two studies reporting that school principals' cultural leadership behaviors were related to organisational commitment (Teyfur, 2015; Uygur \& Yildırım, 2011). In these studies, school principals' cultural 
leadership behaviours reduced cohesion commitment, but increased identification and internalisation commitment. They reported that cultural leadership behaviours explained $9 \%$ to $32 \%$ of variation in organisational commitment characteristics, and cultural leadership behaviours had a moderate level of explanatory power for explaining identification and internalisation commitment. Besides, in these studies, cultural leadership behaviours had a significant negative relationship with cohesion commitment, and had an explanatory power of 9 to $14 \%$.

School principals' servant leadership behaviours were a predictor of teachers' commitment (Cerit, 2010; Doğan \& Aslan, 2016). Cerit (2010) reported that among servant leadership behaviours, valuing individuals, improving their skills, forming a community, acting authentically, enhancing leadership and sharing leadership were positively and significantly related to organisational commitment. In these two studies, servant leadership explained 61 to $69 \%$ of the variation in organisational commitment. Moreover, Doğan and Aslan stated that servant leadership explained 43 to $49 \%$ of the variation in normative, affective and continuance commitment.

Çokluk and Y1lmaz (2010) asserted that supportive leadership positively predicted organisational commitment while commanding leadership reduced commitment. Similarly, Yaman and Özer (2015) pointed out that behaviors that improve and support teachers were positively and significantly related to teachers' organizational commitment. Şama and Kolamaz (2011) showed that with developing ad supportive leadership behaviors, cohesion commitment decreased, but identification and internalization commitment increased.

Bozkuş and Gündüz (2016) found that spiritual leadership increased commitment in teachers, and strongly predicted affective and normative commitment.

In two different studies, behaviors of managing change and talent where reported to be related to teachers' organizational commitment. Çağrıcı and Savaş (2016) stated that as school administrators exhibit more behaviors of implementing change and other behaviors related to change, teachers' organizational commitment increase. On the other hand, Aytaç (2015) demonstrated that school principals' leadership behaviors in the form of talent management predicted teachers' commitment. Besides, strategic talent and working with others, which are talent management characteristics, were important predictors of organizational commitment.

Table 1. Leadership Approaches and Models As Predictors of Organisational Commitment or its Subdimensions

Predictive leadership approaches and models

Change leadership

Working together with others

Strategic talent

Supportive and developing leadership

Inspirational motivation

Individual interest

intellectual stimulation

Transformational leadership

Behavioral ethics

ethics in decision-making

Ethical behaviours

Climatic ethics

Ethical leadership behaviors

Responsibility Tolerance

Valuing individuals,

developing individuals,

acting authentically

Servant leadership

Cultural leadership

Shared leadership

\section{References}

Çağricı \& Savaş (2016)

Aytaç (2015)

Çokluk \& Y1lmaz (2010)

Şama \& Kolamaz (2011)

Buluç (2009)

Çetin \& Aydın (2012)

Kul \& Güçlü (2010)

Bektaş, Çoğaltay \& Sökmen (2014)

Akan \& Yalçın (2015)

Ayık, Yücel \& Savaş (2014)

Uğurlu, Sincar \& Çınar (2013)

Uğurlu \& Üstüner (2011)

Madenoğlu, Uysal, Sarıer \&

Banoğlu (2014)

Okçu (2014)

Cerit (2010)

Doğan \& Aslan (2016)

Uygur \& Yildırım (2011)

Teyfur (2015)

Uslu \& Beycioğlu (2013) 


\begin{tabular}{lll}
\hline & & \\
\hline & $\begin{array}{l}\text { Spiritual leadership } \\
\text { commitment }\end{array}$ & Bozkuş \& Gündüz (2016) \\
\hline & $\begin{array}{l}\text { Supportive and developing leadership } \\
\text { Transformational leadership }\end{array}$ & References \\
\hline Transformational leadership & Yaman \& Özer (2015) \\
\hline Transformational leadership & Çetin \& Aydın (2012) \\
\hline Charismatic & Akan \& Yalçın (2015) \\
\hline Ethical leadership & Arabacı, Alanoğlu \& Doğan (2014) \\
\hline Instructional leadership & Okçu (2014) \\
\hline Shared leadership & Yaman \& Özer (2015) \\
\hline
\end{tabular}

\section{Relationships Between Leadership Behaviours and the Subdimensions of Organisational Commitment}

\section{Relationships with Cohesion Commitment}

In five studies, there are findings revealing a significant and negative relationship between cohesion commitment and different leadership behaviors (Kul \& Güçlü, 2010; Okçu, 2014; Şama \& Kolamaz, 2011; Teyfur, 2015; Uygur \& Y1ldırım, 2011). These studies reported significant and negative relationships between supportive leadership, cultural leadership, ethical leadership dimensions (i.e. tolerance, justice, responsibility, honesty and democratic behaviors) and cohesion commitment, and between transformational leadership and cohesion commitment. Furthermore, Bektaş, Çoğaltay, and Sökmen (2014) found a significant and positive relationship between laissez-faire and transactional leadership and cohesion leadership. Yet, Akan and Yalçın (2015) did not find a significant relationship between the same variables. The decrease in cohesion commitment shows that teachers' superficial behaviors also decreased, and they are attached to their schools more strongly.

\section{Relationships with Continuance Commitment}

In seven studies examined, there are findings revealing a significant and positive relationship between continuance commitment and different leadership behaviors (Arabacı, Alanoğlu \& Doğan, 2014; Aytaç, 2015; Bozkuş \& Gündüz, 2016; Çetin \& Aydın, 2012; Çokluk \& Yılmaz, 2010; Doğan \& Aslan, 2016). They reported that there were significant and positive relationships between supportive leadership, servant leadership, spiritual leadership, talent management dimensions of strategic talent and working with others and continuance commitment, and between charismatic leadership, ethics in decision-making, transformational leadership dimensions of inspirational motivation, individual interest and intellectual stimulation and continuance commitment. Unlike these findings, three studies could not reveal a relationship between continuance commitment and certain leadership behaviors. These behaviors are instructional leadership, shared leadership and ethical leadership (Uslu \& Beycioğlu, 2013; Uğurlu, Sincar \& Çınar, 2013; Yaman \& Özer, 2015). Considering that continuance commitment refers to the commitment to school due to an obligation, leadership behaviors can be said to strengthen this obligatory commitment.

\section{Identification and Internalisation Commitment}

In seven different studies examined, different leadership behaviors were reported to be significantly and positively related to identification and internalization commitment. These behaviors include supportive leadership, cultural leadership, ethical leadership and transformational leadership (Bektaş, Çoğaltay \& Sökmen, 2014; Kul \& Güçlü, 2010; Okçu, 2014; Şama \& Kolamaz, 2011; Uygur \& Yıldırım, 2011; Teyfur, 2015). Moreover, two studies also found that operational leadership was significantly and positively related to internalization commitment (Bektaş, Çoğaltay \& Sökmen, 2014; Kul \& Güçlü, 2010). However, in two studies, there are inconsistent findings regarding the relationship between transactional leadership and identification (Akan \& Yalçın, 2015; Bektaş, Çoğaltay \& Sökmen, 2014)

\section{Affective and Normative Commitment}

In six different studies examined, there are findings showing that different leadership behaviours were significantly and positively related to affective and normative commitment (Arabac1, Alanoğlu \& Doğan, 2014; Ayık, Yücel \& Savaş, 2014; Bozkuş \& Gündüz, 2016; Doğan \& Aslan, 2016; Uğurlu, Sincar \& Çınar, 2013; Uslu \& Beycioğlu, 2013). These behaviors include servant leadership, shared leadership, spiritual leadership, 
charismatic leadership and ethical leadership. Additionally, there were significant and positive relationships between individual interest and intellectual stimulation and affective commitment, and between transformational leadership and normative commitment (Çetin \& Aydın, 2012). Çokluk and Yılmaz (2010) revealed a significant and positive relationship between supportive leadership and affective commitment and a significant and negative relationship between commanding leadership and affective commitment.

The relationships of different leadership behaviors with the subdimensions of organizational commitment were evaluated in the context of mutual causality. Although the findings revealing relationships in the studies examined do not provide causal relationships, they allow for making certain predictions. In this regard, various conclusions can be drawn. In an environment where school administrators support individuals, common values are emphasized and collaboration and communication are strong, teachers' cohesion commitment decreases, or in other words, teachers perform less superficial behaviors. Besides, teachers' continuance commitment increases in that case. This type of leadership behaviors exhibited by administrators force teachers to keep staying in their institutions. However, it can be stated that as school administrators show interest in individuals, make efforts in forming common visions and objectives, support a culture of collaboration and trust and set an example for their staff, teachers' identification, internalisation, the affective and normative commitment would increase.

Table 2. Principals' Predictive Leadership Behaviours Towards Teachers' Organisational Commitment

\begin{tabular}{ll}
\hline Leadership behaviors & References \\
\hline $\begin{array}{l}\text { Forming shared visions and } \\
\text { objectives }\end{array}$ & $\begin{array}{l}\text { Çağrıcı \& Savaş (2016), Buluç (2009), Kul \& Güçlü (2010), Bektaş, } \\
\text { Çoğaltay \& Sökmen (2014), Akan \& Yalçın (2015), Doğan \& Aslan } \\
(2016) \text { Cerit (2010), Bozkuş \& Gündüz (2016). }\end{array}$ \\
\hline Culture of collaboration & $\begin{array}{l}\text { Aytaç (2015), Okçu (2014), Ayı, Yücel \& Savaş (2014,) Cerit (2010), } \\
\text { Doğan \& Aslan (2016) }\end{array}$ \\
\hline $\begin{array}{l}\text { Enhancing communication and } \\
\text { interaction }\end{array}$ & $\begin{array}{l}\text { Buluç (2009), Şama \& Kolamaz (2011), Çokluk \& Yılmaz (2010), Okçu } \\
\text { (2014), Cerit (2010), Uslu \& Beycioğlu (2013) }\end{array}$ \\
\hline $\begin{array}{l}\text { Showing individual interest and } \\
\text { value }\end{array}$ & $\begin{array}{l}\text { Buluç (2009), Çetin \& Aydın (2012), Kul \& Güçlü (2010), Bektaş, } \\
\text { Çoğaltay \& Sökmen (2014), Akan \& Yalçın (2015), Cerit (2010), Doğan }\end{array}$ \\
\hline $\begin{array}{l}\text { Exhibiting supportive and } \\
\text { developing behaviours }\end{array}$ & $\begin{array}{l}\text { Çokluk \& Y1lmaz (2010), Şama \& Kolamaz (2011), Cerit (2010), Doğan } \\
\text { \& Aslan (2016) }\end{array}$ \\
\hline $\begin{array}{l}\text { Forming a working culture based } \\
\text { on justice, respect and trust }\end{array}$ & $\begin{array}{l}\text { Ayık, Yücel \& Savaş (2014), Uğurlu, Sincar \& Çınar (2013), Uğurlu \& } \\
\text { Üstüner (2011), Madenoğlu, Uysal, Sarır \& Banoğlu (2014), Okçu } \\
\text { (2014) Cerit (2010), Teyfur (2015), Uğurlu \& Üstüner (2011) }\end{array}$ \\
\hline $\begin{array}{l}\text { Sharing control and responsibility } \\
\text { among employees }\end{array}$ & \begin{tabular}{l} 
Uslu \& Beycioğlu (2013), Yetim (2016) \\
\hline $\begin{array}{l}\text { Establishing common values and } \\
\text { symbols in school }\end{array}$
\end{tabular} \\
\hline $\begin{array}{l}\text { Managing and maintaining change } \\
\text { Buluç (2009), Çetin \& Aydın (2012), Uygur \& Yıldı̈ım (2011), Bozkuş } \\
\text { \& Gündüz (2016), Uğurlu \& Üstüner (2011) }\end{array}$ \\
$\begin{array}{l}\text { Çağrıcı \& Savaş (2016), Çetin \& Aydın (2012), Buluç (2009), Kul \& } \\
\text { Güçlü (2010), Bektaş, Çoğaltay \& Sökmen (2014), Akan \& Yalçn } \\
\text { (2015) }\end{array}$ \\
\hline
\end{tabular}

Considering all of the above findings together, the leadership behaviours that can be influential on teachers' organisational commitment can be indicated as follows (see Table 2): forming a common objective and vision in school, promoting a culture of cooperation, enhancing communication and interaction, showing interest and appreciation of individuals, supportive and constructive behaviours, forming a working culture based on justice, respect and trust, sharing control and responsibilities, and managing and maintaining change in school.

\section{Discussion and Conclusion}

This study aimed at revealing the types of leadership behaviors that are reported to be potentially related to teachers' organizational commitment in the literature. According to the common findings of the studies examined, as school principals performed a higher level of leadership behaviors, teachers' level of commitment to their schools increased. This result overlaps with Mathieu and Zazac's (1990) meta-analysis study on the roots and results of organizational commitment in which they concluded that organizational and individual characteristics, 
as well as leader-group relationships, constitute the basis for organizational commitment. Similarly, in their systematic review on the relationship between administrators' leadership behaviors and nurses' intent to stay in their position and commitment, Cowden, Cummings, and Profetto-Mcgrath (2011) found that transformational leadership and supportive working environments increased nurses' intent to stay and commitment. In addition, they also observed that relational leadership increased nurses' intent to stay, the quality of their working environment and commitment. On the other hand, in their systematic review, Choi and Tang (2009) listed school principals' not allowing for any freedom, weakness of collaboration and not being able to ensure learning opportunities and participation to decisions as the factors that reduce teachers' commitment. This result shows that school principals have an influence on teachers' commitment to their school.

The dimensions that were often addressed in the studies included leadership behaviours that are forming a common objective and vision in school, promoting a culture of cooperation, enhancing communication and interaction, showing interest and appreciation of individuals, supportive and constructive behaviours, forming a working culture based on justice, respect and trust, sharing control and responsibilities, and managing and maintaining change in school. In this regard, when these variables are considered as a whole, it can be argued that individual-oriented behaviors have a potential of strengthening organizational commitment. Besides, it was seen in this review that teachers' organizational commitment had strong relationships with transformational leadership, servant leadership, and ethical leadership behaviors, respectively according to their strength, and these behaviors were significant predictors of commitment as well. Meyer, Stanley, Herscovitch, and Topolnytsky (2002) conducted a meta-analysis on the consequences and antecedents of affective, continuance and normative commitment, and revealed strong relationships between organizational commitment and organizational justice and transformational leadership. In their systematic review, Cummings et al. (2010) found that administrators' relational and transformational leadership skills positively affected nurses' working in cooperation and their commitment and motivation. Lastly, in their study on the relationships between leadership, commitment and culture, Jackson, Meyer, and Wang (2013) reported that effective and normative commitment w positively related to transformational and charismatic leadership, but negatively related to laissez-faire leadership.

\section{Implications for School Administrators}

Teachers' commitment can be promoted by school administrators' establishing interpersonal communication with them, arousing the feeling of 'us' within the group and gaining the confidence of the school staff. Therefore, it is important to develop a school culture in which nobody is marginalized, everybody sees the value, and there is cooperation, support, and trust. In this respect, school principals should receive training for developing leadership behaviors to have quality relationships with their staff.

In this study, relationship-oriented leadership behaviors of school administrators were demonstrated to have the potential of enhancing teachers' organizational commitment, which is thought to be a contribution to theory. However, there are certain limitations to this study. Only the studies conducted in the Turkish context were examined. These studies were relational or correlational, which makes it difficult to make interpretations for causality and weakens their generalisability. Moreover, this study is limited to the studies that could be reached through the databases searched.

Many studies show that different patterns in school principals' leadership behaviors are related to teachers commitment. Accordingly, further research can be extended to mediator variables that can strengthen the relationship between leadership and commitment. On the other hand, studies can be conducted to test cause-effect relationships. The present study can be replicated with theses and dissertations. It can also be extended to include studies published in the international literature. 
Cansoy, R. \& Polatcam, M. (2019). The Relationship Between School Principals' Leadership and Teachers' Organisational Commitment: A Systematic Review. Bartin University Journal of Faculty of Education, 8(1), 1-

\begin{tabular}{|c|c|c|c|c|c|c|c|}
\hline No. & Authors & Participants & Measurement tools- dimensions & $\begin{array}{l}\text { Reliability } \\
\text { Cronbach } \alpha\end{array}$ & $\begin{array}{l}\text { Analysis } \\
\text { method }\end{array}$ & Findings & Statistics \\
\hline 1 & Çağrıcı \& Savaş (2016) & $\begin{array}{l}252 \text { elementary school } \\
\text { teachers }\end{array}$ & $\begin{array}{l}\text { Change leadership } \\
\text { Leaders' behaviour of establishing the change } \\
\text { Leaders' behaviour of implementing the change } \\
\text { Organisational commitment }\end{array}$ & .95 & $\begin{array}{l}\text { Correlation } \\
\text { Regression }\end{array}$ & $\begin{array}{l}\text { School principals' change leadership behaviours predict } \\
\text { teachers' organizational commitment. }\end{array}$ & $\begin{array}{l}r=.42 \\
R^{2}=.225 \\
\beta=.431\end{array}$ \\
\hline 2 & Şama \& Kolamaz (2011) & $\begin{array}{l}180 \text { elementary and } \\
\text { high school teachers }\end{array}$ & $\begin{array}{l}\text { Supportive and developing leadership } \\
\text { approaches }\end{array}$ & $\begin{array}{l}.92 \text { (reported from } \\
\text { the original scale). } \\
\text { Reported to be } \\
\text { between } .79 \text { and } \\
.93 .\end{array}$ & $\begin{array}{l}\text { Correlation } \\
\text { Regression }\end{array}$ & $\begin{array}{l}\text { School principals supportive leadership and developing } \\
\text { leadership characteristics are negatively related to cohesion } \\
\text { commitment. } \\
\text { Supportive and developing leadership predict identification } \\
\text { commitment. } \\
\text { Supportive and developing leadership predict internalization } \\
\text { commitment. }\end{array}$ & $\begin{array}{l}\mathrm{r}=-.27 \\
\mathrm{r}=-.30 \\
R^{2}=.45 \\
\mathrm{r}=.66 / \mathrm{r}=.63 \\
R^{2}=.30 \\
\mathrm{r}=.53 / \mathrm{r}=.53\end{array}$ \\
\hline 3 & Çokluk \& Yilmaz (2010) & $\begin{array}{l}200 \text { elementary school } \\
\text { teachers }\end{array}$ & $\begin{array}{l}\text { Leadership behaviours } \\
\text { Guiding leadership behaviours } \\
\text { Commanding leadership behaviours } \\
\text { Organisational commitment } \\
\text { Affective commitment, Continuance } \\
\text { commitment }\end{array}$ & Not reported. & $\begin{array}{l}\text { Correlation } \\
\text { Regression }\end{array}$ & $\begin{array}{l}\text { Supportive leadership predicts organisational commitment. } \\
\text { As supportive leadership increases, affective commitment } \\
\text { increases. } \\
\text { Supportive leadership and continuance commitment are } \\
\text { inversely related. } \\
\text { Commanding leadership are inversely related to, and predicts } \\
\text { organizational commitment. } \\
\text { Commanding leadership are inversely related to, and predicts } \\
\text { affective commitment. } \\
\text { Commanding leadership are inversely related to, and predicts } \\
\text { continuance commitment. }\end{array}$ & $\begin{array}{l}\left(\mathrm{R}^{2}=.24\right) \\
\left(\mathrm{R}^{2}=.23\right) \\
\left(\mathrm{R}^{2}=.09\right) \\
\left(\mathrm{R}^{2}=.22\right) \\
\left(\mathrm{R}^{2}=.23\right) \\
\left(\mathrm{R}^{2}=.07\right)\end{array}$ \\
\hline 4 & Cerit (2010) & $\begin{array}{l}563 \text { elementary school } \\
\text { teachers }\end{array}$ & $\begin{array}{l}\text { Servant leadership } \\
\text { Valuing individuals, Developing individuals } \\
\text { Forming a community, Acting authentically } \\
\text { Improving leadership, Sharing leadership } \\
\text { Organisational commitment }\end{array}$ & $\begin{array}{l}.98 \\
.88-.92 \\
.91\end{array}$ & $\begin{array}{l}\text { Correlation } \\
\text { Regression }\end{array}$ & $\begin{array}{l}\text { Valuing individuals, developing their skills, forming a } \\
\text { community, acting authentically, enhancing leadership and } \\
\text { sharing leadership is positively related to organisational } \\
\text { commitment. } \\
\text { Valuing individuals, developing their skills and } \\
\text { acting authentically predict organisational commitment. } \\
\text { Servant leadership predicts organisational commitment. }\end{array}$ & $\begin{array}{l}\beta=.20, \quad \beta=.47, \\
\beta=.45 \\
\left(R^{2}=.69\right)\end{array}$ \\
\hline 5 & Doğan \& Aslan (2016) & $\begin{array}{l}336 \text { teachers working in } \\
\text { special education } \\
\text { training centers and } \\
\text { science end arts centers. }\end{array}$ & $\begin{array}{l}\text { Servant leadership } \\
\text { Organisational commitment } \\
\text { Affective commitment, } \\
\text { commitment } \\
\text { Normative commitment }\end{array}$ & $\begin{array}{l}.98 \\
.85 \\
.93-89\end{array}$ & $\begin{array}{l}\text { Descriptive } \\
\text { Correlation } \\
\text { Regression }\end{array}$ & $\begin{array}{l}\text { Servant leadership are positively related to affective } \\
\text { commitment, continuance commitment and normative } \\
\text { commitment. } \\
\text { Servant leadership predicts affective commitment. } \\
\text { Servant leadership predicts continuance commitment. } \\
\text { Servant leadership predicts normative commitment. } \\
\text { Servant leadership predicts organisational commitment. }\end{array}$ & $\begin{array}{l}\mathrm{r}=.66-.70 \\
\left(\mathrm{R}^{2}=.43\right) \\
\left(\mathrm{R}^{2}=.44\right) \\
\left(\mathrm{R}^{2}=.49\right) \\
\left(\mathrm{R}^{2}=.61\right)\end{array}$ \\
\hline 6 & Yaman \& Özer (2015) & $\begin{array}{ll}378 \text { middle } & \text { school } \\
\text { teachers } & \end{array}$ & $\begin{array}{l}\text { Instructional leadership } \\
\text { Organisational commitment }\end{array}$ & $\begin{array}{l}.97 \\
.90\end{array}$ & $\begin{array}{l}\text { Descriptive } \\
\text { Correlation }\end{array}$ & $\begin{array}{l}\text { Instructional leadership behaviours are positively related to } \\
\text { teachers' organizational commitment behaviors. } \\
\text { Normative commitment is the only dimension of } \\
\text { organizational commitment that has a significant relationship } \\
\text { with instructional leadership. } \\
\text { Supporting and developing teachers is the instructional } \\
\text { leadership dimension with the strongest relationship with } \\
\text { teacher commitment. }\end{array}$ & $\begin{array}{l}\mathrm{r}=.14 \\
\mathrm{r}=.24 \\
\mathrm{r}=.19\end{array}$ \\
\hline
\end{tabular}


Cansoy \& Polatcan

\begin{tabular}{|c|c|c|c|c|c|c|c|}
\hline 7 & Uygur \& Yildrrım (2011) & $\begin{array}{l}402 \\
\text { elementary } \\
\text { school } \\
\text { teachers }\end{array}$ & $\begin{array}{l}\text { Cultural leadership } \\
\text { Organisational commitment } \\
\text { Cohesion, Identification, Internalisation }\end{array}$ & $\begin{array}{l}.94 \\
.79-.93 \text { (values } \\
\text { reported in the } \\
\text { original study) }\end{array}$ & $\begin{array}{l}\text { Descriptive } \\
\text { Correlation }\end{array}$ & $\begin{array}{l}\text { School principals' cultural leadership roles are inversely } \\
\text { related to and predict, cohesion commitment. } \\
\text { School principals' cultural leadership roles are positively } \\
\text { related to and predict, identification and internalization } \\
\text { commitment. }\end{array}$ & $\begin{array}{l}\left(r^{2}=.14\right) \\
\left(r^{2}=.32\right) \\
\left(r^{2}=.24\right)\end{array}$ \\
\hline 8 & Teyfur (2015) & $\begin{array}{l}530 \text { middle } \\
\text { school } \\
\text { teachers }\end{array}$ & $\begin{array}{l}\text { Cultural leadership } \\
\text { Organisational commitment } \\
\text { Cohesion, Identification, Internalisation }\end{array}$ & $\begin{array}{l}.92 \\
.79-.93 \text { (values } \\
\text { reported in the } \\
\text { original study) }\end{array}$ & $\begin{array}{l}\text { Descriptive } \\
\text { Causal } \\
\text { comparison } \\
\text { Correlation }\end{array}$ & $\begin{array}{l}\text { School principals' cultural leadership roles are inversely } \\
\text { related to and predict, cohesion commitment. } \\
\text { School principals' cultural leadership roles are positively } \\
\text { related to and predict, identification and internalization } \\
\text { commitment. }\end{array}$ & $\begin{array}{l}\left(r^{2}=.09\right) \\
\left(r^{2}=.15\right) \\
\left(r^{2}=.21\right)\end{array}$ \\
\hline 9 & Uslu \& Beycioğlu (2013) & $\begin{array}{l}324 \\
\text { elementary } \\
\text { school } \\
\text { teachers }\end{array}$ & $\begin{array}{l}\text { Shared leadership } \\
\text { Organisational commitment } \\
\text { Affective commitment, Continuance } \\
\text { commitment } \\
\text { Normative commitment }\end{array}$ & .92 & $\begin{array}{l}\text { Descriptive } \\
\text { Causal } \\
\text { comparison } \\
\text { Correlation }\end{array}$ & $\begin{array}{l}\text { School principals' cultural leadership roles are positively } \\
\text { related to organizational commitment behavior, and shared } \\
\text { leadership is explanatory. } \\
\text { Affective and normative commitment positively related to } \\
\text { shared leadership. }\end{array}$ & $\begin{array}{l}\mathrm{r}=.52 \\
\mathrm{r}=.53\end{array}$ \\
\hline 10 & Yetim (2016) & $\begin{array}{l}473 \\
\text { elementary } \\
\text { school } \\
\text { teachers }\end{array}$ & $\begin{array}{l}\text { Distributed leadership } \\
\text { Organisational commitment }\end{array}$ & Not reported. & Correlational & $\begin{array}{l}\text { School principals' distributed leadership behaviours are } \\
\text { positively related to teachers" organizational commitment. }\end{array}$ & $\mathrm{r}=.73$ \\
\hline 11 & Bozkuş \& Gündüz (2016) & $\begin{array}{l}333 \\
\text { elementary, } \\
\text { middle and } \\
\text { high school } \\
\text { teachers }\end{array}$ & $\begin{array}{l}\text { Spiritual leadership } \\
\text { Organisational commitment } \\
\text { Affective commitment, Normative commitment } \\
\text { Continuance commitment }\end{array}$ & $\begin{array}{l}.94 \\
.58-.79 \text { (Reported } \\
\text { from the adapted } \\
\text { version.) }\end{array}$ & $\begin{array}{l}\text { Correlational } \\
\text { Structural } \\
\text { equation } \\
\text { modeling }\end{array}$ & $\begin{array}{l}\text { Spiritual leadership positively predicts organizational } \\
\text { commitment. } \\
\text { Spiritual commitment positively predicts affective, } \\
\text { continuance and normative commitment. }\end{array}$ & $\begin{array}{l}\beta=.23 \\
\beta=.39, \beta=.27 \\
\beta=.37\end{array}$ \\
\hline 12 & Aytaç (2015) & $\begin{array}{l}402 \text { high } \\
\text { school } \\
\text { teachers }\end{array}$ & $\begin{array}{l}\text { Talent management leadership } \\
\text { Working together with others, Values } \\
\text { Personal characteristics, Strategic talent } \\
\text { Organisational commitment } \\
\text { Affective commitment, Normative commitment } \\
\text { Continuance commitment }\end{array}$ & .85 & $\begin{array}{l}\text { Correlation } \\
\text { Regression }\end{array}$ & $\begin{array}{l}\text { Subdimensions of talent management are related to } \\
\text { organisational commitment. } \\
\text { Strategic talent variable predicts organisational commitment. } \\
\text { Working with others predicts organizational commitment. } \\
\text { Personal characteristics, working with others values together } \\
\text { positively predict affective commitment. } \\
\text { Strategic talent and working with others together predict } \\
\text { continuance commitment. } \\
\text { Strategic talent predicts normative commitment. }\end{array}$ & $\begin{array}{l}\mathrm{r}=.17-.91 \\
\beta=.53 \\
\beta=.40 \\
\left(\mathrm{R}^{2}=.90\right) \\
\left(\mathrm{R}^{2}=.12\right) \\
\beta=.86\end{array}$ \\
\hline 13 & Arabacı, Alanoğlu \& Doğan (2014) & $\begin{array}{l}217 \\
\text { elementary } \\
\text { and high } \\
\text { school } \\
\text { teachers }\end{array}$ & $\begin{array}{l}\text { Charismatic Leadership } \\
\text { Setting a vision, Showing environmental } \\
\text { sensitivity, Exhibiting extraordinary behaviors } \\
\text { Taking personal risks, Sensitivity to member } \\
\text { needs, Not maintaining the existing situation } \\
\text { Organisational commitment } \\
\text { Affective commitment, Normative commitment } \\
\text { Continuance commitment }\end{array}$ & .85 & $\begin{array}{l}\text { Descriptive } \\
\text { Correlation }\end{array}$ & $\begin{array}{l}\text { School principals' charismatic leadership characteristics are } \\
\text { positively related to teachers' organizational commitment. } \\
\text { Setting a vision, showing environmental sensitivity, taking } \\
\text { personal risks, communication and maintenance are positively } \\
\text { related to organizational commitment. } \\
\text { Charismatic leadership has the strongest relationship with the } \\
\text { dimensions that are affective and continuance commitment. It } \\
\text { has a weaker relationship with normative commitment. }\end{array}$ & $\begin{array}{l}\mathrm{r}=.19 \\
\mathrm{r}=.14-.20\end{array}$ \\
\hline
\end{tabular}


School Principals' Leadership and Teacher Commitment

\begin{tabular}{|c|c|c|c|c|c|c|c|}
\hline \multicolumn{8}{|c|}{ Apendix I. Continuation } \\
\hline 14 & Aylk, Yücel \& Savaş (2014) & $\begin{array}{l}267 \\
\text { elementary } \\
\text { school } \\
\text { teachers }\end{array}$ & $\begin{array}{l}\text { Ethical leadership } \\
\text { Communicative ethics, climatic ethics, ethics in } \\
\text { decision-making, behavioral ethics } \\
\text { Organisational commitment } \\
\text { Affective commitment, continuance } \\
\text { commitment, normative commitment }\end{array}$ & $\begin{array}{l}.98 \\
.92-.96 \\
.91 \\
.76-.83\end{array}$ & $\begin{array}{l}\text { Descriptive } \\
\text { Correlation } \\
\text { Regression }\end{array}$ & $\begin{array}{l}\text { School administrators' ethical leadership behaviours are } \\
\text { positively related to teachers' organisational commitment. } \\
\text { There are positive relationships between ethical leadership } \\
\text { and all subdimensions of organisational commitment. } \\
\text { Behavioural ethics is a predictor of affective commitment. } \\
\text { Behavioural ethics is a predictor of continuance commitment. } \\
\text { Ethics in decision-making is a predictor of continuance } \\
\text { commitment. } \\
\text { Behavioural ethics is a predictor of normative commitment. } \\
\text { Ethics in decision-making is a predictor of normative } \\
\text { commitment. }\end{array}$ & $\begin{array}{l}\mathrm{r}=.51 \\
\mathrm{r}=.27-.51 \\
\beta=.55 \\
\beta=.90 \\
\beta=-.29 \\
\beta=.59 \\
\beta=.29\end{array}$ \\
\hline 15 & Uğurlu, Sincar \& Çınar (2013) & $\begin{array}{l}195 \text { high } \\
\text { school } \\
\text { teachers }\end{array}$ & $\begin{array}{l}\text { Ethical leadership } \\
\text { Organisational commitment } \\
\text { Affective commitment, normative commitment } \\
\text { and continuance commitment }\end{array}$ & $\begin{array}{l}.97 \\
.76 \\
\text { (reported from } \\
\text { the original } \\
\text { study). }\end{array}$ & $\begin{array}{l}\text { Descriptive } \\
\text { Regression }\end{array}$ & $\begin{array}{l}\text { Ethical leadership behaviours are positively related to } \\
\text { organizational commitment, and ethical leadership is a } \\
\text { predictor. } \\
\text { Ethical leadership predicts affective and normative } \\
\text { commitment. }\end{array}$ & $\begin{array}{l}\left(\mathrm{R}^{2}=.058\right) \\
\left(\mathrm{R}^{2}=.037\right) \\
\left(\mathrm{R}^{2}=.057\right)\end{array}$ \\
\hline 16 & Uğurlu \& Üstüner (2011) & $\begin{array}{l}1112 \\
\text { elementary, } \\
\text { middle and } \\
\text { high school } \\
\text { teachers }\end{array}$ & $\begin{array}{l}\text { Ethical leadership } \\
\text { Communicative ethics, climatic ethics, ethics in } \\
\text { decision-making, behavioural ethics } \\
\text { Organisational commitment } \\
\text { Affective commitment, continuance } \\
\text { commitment, normative commitment }\end{array}$ & $\begin{array}{l}.98 \\
.89-.98 \\
.73 \\
.73-86 \text { (reported } \\
\text { from the adapted } \\
\text { version of the } \\
\text { scale). }\end{array}$ & Regression & $\begin{array}{l}\text { Administrators' leadership behaviors are a predictor of } \\
\text { teachers' organizational commitment. } \\
\text { Only climatic ethics among administrative ethics behaviors is } \\
\text { a predictor of organizational commitment. }\end{array}$ & $\begin{array}{l}\mathrm{R}^{2}=.14 \\
\beta=.21\end{array}$ \\
\hline 17 & $\begin{array}{l}\text { Madenoğlu, Uysal, Sarier \& Banoğlu } \\
\text { (2014) }\end{array}$ & $\begin{array}{l}940 \text { high } \\
\text { school } \\
\text { teachers }\end{array}$ & $\begin{array}{l}\text { Ethical leadership } \\
\text { Communicative ethics, climatic ethics, ethics in } \\
\text { decision-making, behavioral ethics } \\
\text { Organisational commitment }\end{array}$ & .99 & Regression & $\begin{array}{l}\text { School principals' ethical leadership behaviours predict } \\
\text { teachers' organisational commitment. }\end{array}$ & $\beta=.74$ \\
\hline 18 & Okçu (2014) & $\begin{array}{l}590 \text { high } \\
\text { school } \\
\text { teachers }\end{array}$ & $\begin{array}{l}\text { Ethical leadership } \\
\text { Tolerance, justice, responsibility, honesty, } \\
\text { democracy } \\
\text { Organisational commitment } \\
\text { Cohesion, Identification, Internalisation }\end{array}$ & $\begin{array}{l}.97 \\
.82-.94 \\
.91 \\
.82-.93\end{array}$ & $\begin{array}{l}\text { Correlation } \\
\text { Regression }\end{array}$ & $\begin{array}{l}\text { There are negative relationships between the ethical } \\
\text { leadership dimensions of tolerance, justice, responsibility, } \\
\text { honesty and democracy and cohesion commitment. } \\
\text { There are positive relationships between the ethical leadership } \\
\text { dimensions of tolerance, justice, responsibility, honesty and } \\
\text { democracy and identification and internalisation commitment. } \\
\text { The responsibility dimension predicts the identification } \\
\text { commitment. } \\
\text { The tolerance dimension predicts the internalization } \\
\text { commitment. } \\
\text { Ethical leadership behaviours do not predict the cohesion } \\
\text { dimension (i.e. superficial behaviors). }\end{array}$ & $\begin{array}{l}\mathrm{r}=-.12 /-.22 \\
\mathrm{r}=.21 / .37\end{array}$ \\
\hline
\end{tabular}


Cansoy \& Polatcan

\begin{tabular}{|c|c|c|c|c|c|c|c|}
\hline 19 & Buluç (2009) & $\begin{array}{l}250 \\
\text { elementary } \\
\text { school } \\
\text { teachers }\end{array}$ & $\begin{array}{l}\text { Multifactorial leadership } \\
\text { Transformational leadership: Idealised effect } \\
\text { (behavior), idealized effect (attributed), } \\
\text { inspirational motivation, intellectual } \\
\text { stimulation, individual support } \\
\text { Operational leadership: Conditional reward, } \\
\text { Managing with exceptions (active), managing } \\
\text { with exceptions (passive), laissez-faire } \\
\text { leadership } \\
\text { Organisational commitment }\end{array}$ & $\begin{array}{l}.94 \\
.65-.86 \\
.69 \\
.41-.81 \\
.93\end{array}$ & $\begin{array}{l}\text { Correlation } \\
\text { Regression }\end{array}$ & $\begin{array}{l}\text { The leadership styles of idealised effect (behaviour), idealised } \\
\text { effect (attributed), inspirational motivation, intellectual } \\
\text { stimulation, individual support and conditional reward are } \\
\text { positively related to organisational commitment. } \\
\text { Inspirational motivation is a predictor of organisational } \\
\text { commitment. }\end{array}$ & $r=.43-r=.64$ \\
\hline 20 & Çetin \& Aydın (2012) & $\begin{array}{l}465 \text { high } \\
\text { school } \\
\text { teachers }\end{array}$ & $\begin{array}{l}\text { Transformational leadership } \\
\text { Inspirational motivation, Idealised effect, } \\
\text { Individual interest, Mental stimulation } \\
\text { Organisational commitment } \\
\text { Affective commitment, normative commitment } \\
\text { and continuance commitment }\end{array}$ & .78 & $\begin{array}{l}\text { Descriptive } \\
\text { Correlation } \\
\text { Regression }\end{array}$ & $\begin{array}{l}\text { School administrators' individual interest and mental } \\
\text { stimulation predict affective commitment. } \\
\text { Administrators' transformational leadership characteristics of } \\
\text { inspirational motivation, individual interest and mental } \\
\text { stimulation } \\
\text { have significant relationships with continuance commitment. } \\
\text { There are significant relationships between administrators' } \\
\text { individual interest and teachers' normative commitment. }\end{array}$ & $\mathrm{R}^{2}=30$ \\
\hline 21 & Kul \& Güçlü (2010) & $\begin{array}{l}291 \text { physical } \\
\text { education } \\
\text { teachers }\end{array}$ & $\begin{array}{l}\text { Multifactorial leadership } \\
\text { Transformational leadership, } \\
\text { Operational leadership } \\
\text { Organisational commitment } \\
\text { Cohesion, Identification, Internalisation }\end{array}$ & Not reported. & $\begin{array}{l}\text { Descriptive } \\
\text { Correlation } \\
\text { Regression }\end{array}$ & $\begin{array}{l}\text { School administrators' transformational leadership } \\
\text { characteristics are negatively related to cohesion commitment. } \\
\text { School administrators' transformational leadership behaviors } \\
\text { are positively related to identification commitment. } \\
\text { school administrators' transformational leadership } \\
\text { characteristics are positively related to identification } \\
\text { commitment. } \\
\text { Transformational leadership is a predictor of organizational } \\
\text { commitment. } \\
\text { Operational leadership positively related to organizational } \\
\text { commitment. } \\
\text { Operational leadership is not a predictor of organizational } \\
\text { commitment. }\end{array}$ & $\begin{array}{l}r=-.34 \\
r=.51 \\
r=.80 \\
\beta=.39 \\
r=.72\end{array}$ \\
\hline 22 & Bektaş, Çoğaltay \& Sökmen (2014) & $\begin{array}{l}296 \\
\text { elementary } \\
\text { school } \\
\text { teachers }\end{array}$ & $\begin{array}{l}\text { Multifactorial leadership } \\
\text { Transformational leadership, Continuance } \\
\text { leadership } \\
\text { Laissez-faire leadership } \\
\text { Organisational commitment } \\
\text { Cohesion, Identification, Internalisation }\end{array}$ & $\begin{array}{l}.95 \\
.76-98 \\
.90 \\
.88-90\end{array}$ & $\begin{array}{l}\text { Descriptive } \\
\text { Correlation } \\
\text { Regression }\end{array}$ & $\begin{array}{l}\text { Transformational leadership and identification and } \\
\text { internalization commitment are positively related. } \\
\text { Transformational leadership is positively related to } \\
\text { organizational commitment. } \\
\text { The strongest predictor of organizational commitment is } \\
\text { transformational leadership. } \\
\text { The weakest predictor of organizational commitment is } \\
\text { laissez-faire leadership. } \\
\text { Continuance leadership predicts organizational commitment. } \\
\text { Continuance leadership related to the subdimensions of } \\
\text { commitment. } \\
\text { Laissez-faire leadership is related to cohesion commitment. }\end{array}$ & $\begin{array}{l}\mathrm{r}=.67-\mathrm{r}=.50 \\
\mathrm{r}=.54 \\
\mathrm{R}^{2}=.30 \\
\mathrm{R}^{2}=.01 \\
\mathrm{R}^{2}=.15 \\
\mathrm{r}=.15-\mathrm{r}=.44 \\
\mathrm{r}=.43\end{array}$ \\
\hline
\end{tabular}


School Principals' Leadership and Teacher Commitment

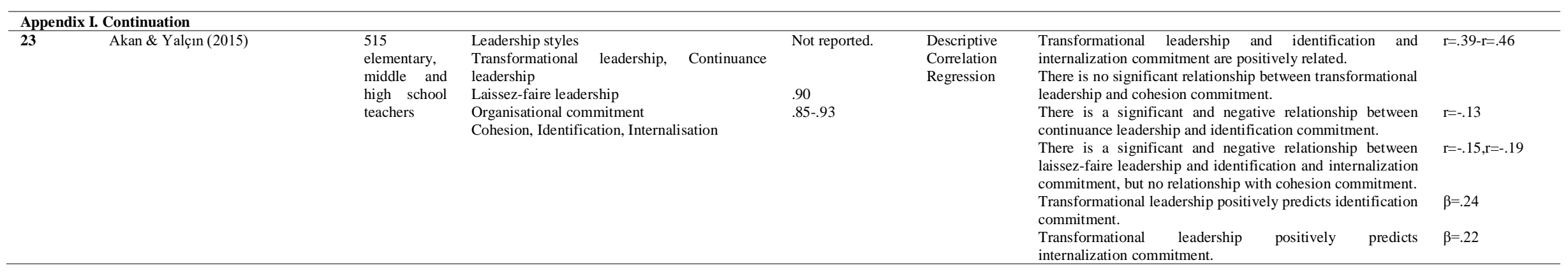




\section{Okul Müdürü Liderliği ve Öğretmen Bağlılı̆̆ İlişkisi: Sistematik Bir Derleme}

\section{Giriş}

Okul müdürü liderliği araştırmaları yaklaşık 50 yıldır eğitimin önemli çalışma alanlarındandır (Waters ve Marzano, 2006). Özellikle ilköğretim ve ortaöğretim düzeyinde sürdürülebilir başarı ve öğretimsel gelişmeler için etkili okul ve müdür liderliği araştırmaların odağını oluşturmaktadır (Heck ve Hallinger, 1996; Spillane, 2003). Nitekim araştırmacılar okul liderliğine ilişkin ilk çalışmaların öğrenci başarısı ve öğretmen performansına vurgu yaptığını belirtmektedirler (Leithwood ve Jantzi, 2005; Murphy ve Vriesenga, 2006; Yukl, 2012). Değişim ve gelişime bağlı olarak son dönem okul yönetimi alanındaki liderlik araştırmaları ise daha çok liderlik stillerine odaklanmıştır. Pek çok araştırmacı liderlik stilini bir örgütün üyelerinin nasıl işlediğini etkileyen önemli bir değişken olarak düşünmektedir. Nitekim bu dönem araştırmalarında okul müdürlerinin sergilediği liderlik stillerinin (dönüşümcü, etkileşimci, işlemsel, dağıtımcı ve öğretimsel) çalışanların algılanan iş doyumu, performans, okul kültürü ve iklimi, örgütsel vatandaşlık, örgütsel adalet, okula katılım ve okul geliştirme gibi davranışlarını etkilediği görülmüştür (Blase ve Blase, 1999; Dinham, 2005; Griffith, 2004; Harris, 2004; Heck ve Larsen ve Marcoulides, 1990; Leithwood ve Jantzi,1990; Marks ve Printy, 2003; Nguni, Sleegers ve Denessen, 2006; Silins, 1994). Day ve Leithwood (2007), okullarda liderliğin önemine yönelik yapılan araştırmaların bulgularının tatmin edici düzeyde olduğunu belirtmektedir. Öte yandan bu çalışmanın temel kavramlarından biri olan öğretmen bağlılığının da okul müdürü liderliği davranışlarından etkilendiği araştırmalarla ortaya konmuştur (Geijsel, Sleegers, Leithwood ve Jantzi, 2003; Ross ve Gray, 2006).

Örgütsel bağlılık alan yazınında süreç içerisinde kapsamlı araştırmalar yapılmıştır (Buchanan, 1974; Eisenberger ve Baik, 2016; Gupta, 2017; Mathieu ve Zajac, 1990; Mathieu ve Farr, 1991; Meyer, ve Allen, 1991; Mowday, Steers ve Porter, 1979; O'Reilly ve Chatman, 1986; Steers, 1977; Yahaya \& Ebrahim, 2016). Örgütsel davranış literatüründe örgütsel bağlllık olumlu bir kavram olarak bilinmektedir. Örgütsel bağlllık, örgütlerde çalışanların işe yönelik davranışlarının anlaşılmasında önemli bir değişsen olarak kabul edilmektedir (Meyer, Stanley, Herscovitch ve Topolnytsky, 2002; Mowday, Steers ve Porter, 1979). Bununla birlikte öğretmenin örgütsel bağlılı̆̆ özel anlamda bireysel performansin geliştirilmesinde, genel anlamda eğitim reformlarının ve eğitsel başarının gerçekleştirilmesinde önemli rol oynamaktadır (Tsui ve Cheng, 1999). Nitekim okullarda yapılan pek çok çalışma öğretmenlerin örgütsel bağlılı̆̆ının, iş performansının, devamsızlığının ve işten ayrılmanın önemli bir yordayıcısı olduğunu göstermiştir (Cheng, 1990; Morris ve Sherman, 1981; Mowday, Porter ve Steers, 1979). Ayrıca bazı araştırmalarda öğretmen lerin motivasyonu, iş tatmini, öz-yeterlik ve bağlıkları arasında olumlu ilişkiler ortaya konulmuştur (Canrinus, Helms-Lorenz, Beijaard, Buitink ve Hofman, 2012; Rosenholtz, 1989).

Okul müdürlerinin liderlik stilleri ile öğretmenlerin örgütsel bağl1lıkları arasındaki ilişkilerin incelendiğgi çalışmaların eğilimlerinin belirlenmesi önemlidir. Bu amaçla bu sistematik derleme çalışmasında okul müdürlerinin liderlik stillerinin (dönüşümcü, işlemsel, öğretimsel ve dağıtımcı vb.) öğretmenlerin örgütsel bağlılığı arasındaki ilişkilerin incelendiği makale çalışmalarının ayrıntılı bir biçimde analiz edilmesi amaçlanmıştır.

\section{Kavramsal Çerçeve}

Okulda olumlu öğrenme iklimi, eğitim programları ve çalışma ortamındaki normların oluşturulması etkili okul müdürlerine bağlıdır (Hallinger, Bickman ve Davis, 1996). Okulların yönetiminde öğretim çalışmalarında aktif rol alma, çalışanlar arasında iletişimi sağlama, çalışanların motivasyonu, bağlılığ 1 ve iş doyumunu artırma, olumlu okul iklimi oluşturma ve öğrenci başarısına katkı sağlama gibi faktörler konusunda okullar arasındaki farklılıklar, okul müdürünün liderliğine bağlanmaktadır (Andrews ve Soder, 1987). Bu bağlamda bir lider olarak okul müdürü, okul personeliyle güvene dayalı ilişkiler kuran, öğretmenlerin bilgi ve beceri geliştiren ve okulun başarısına katkı sağlayan kişi olarak tanımlanmaktadır (Youngs ve King, 2002). Bir başka anlatımla okulda çeşitli roller üstlenen, takipçilerine yön vermek için başkalarıyla birlikte çalışan ve okulun hedeflerine ulaşmak için izleyenlerini etkileyen kişiler olarak ifade edilmektir (Leithwood ve Riehl, 2003). Bununla birlikte eğitim alanındaki gelişmelere bağlı olarak okul yöneticilerinin farklı liderlik stillerini sergilenmesi beklenmektedir. Nitekim okulda vizyon ve misyon oluşturan ve çalışan motivasyonunu artıran dönüşümcü lider (Bass, 1990), okul başarısının artırılmasında eğitim programı ve çalışanlar arasında etkileşimin geliştirilmesinde öğretimsel lider (Blase ve Blase, 1999), mesleki öğrenme toplulukları arasında işbirliğini sağlayan ve takipçilerini karar alma süreçlerine dahil eden dağıtımcı lider (Heck ve Hallinger, 2009), 
takipçilerinden herhangi bir karşılık beklemeden onların yararına çalışan hizmetkar lider (Black, 2010) ve çalışanlar ile iletişim kurarak kişiler arasındaki ilişkilerde uyulması gereken kuralları belirleyen, karar alan ve takipçileriyle paylaşan etik lider gibi pek çok liderlik stili bulunmaktadır (Brown, Trevino ve Harrison, 2005).

Araştırma konusunun bir diğer değişkenini oluşturan öğretmenlerin örgütsel bağlılıkları da öğretmenlerin iş doyumu, performansı ve motivasyonu kadar, etkili okulun işleyişi üzerinde önemli bir faktördür. Öğretmenin bağlılığı, öğretmenin kişisel ihtiyaçlarını karşılama ve okul uğruna çalışma isteğini yansıtmaktadır (Anderman, Belzer ve Smith, 1991). Ayrıca öğretmenlerin bağlılık algıları, okul adına alınan önemli kararlara katılma duygusunu geliştirmektedir (Hart ve Willower, 1994). Örgütsel davranış ve psikoloji alanının (Mathieu ve Zazac, 1990; Reichers, 1985), çalışma konularında biri olan örgütsel bağlılık bir bireyin örgütle özdeşleşmesi, örgütün hedef ve değerlerine olan inancı için çaba göstermesi ve örgüt üyeliğine devam etme isteğidir (Porter, Steers, Mowday ve Boulian, 1974). Bir başka tanımda kişinin örgüt veya grubuna karşı hissettiği bağlanma duygusudur (O'Reilly ve Chatman, 1986). Özetle Cook ve Wall'in (1980) belirttiği gibi örgütsel bağlılık örgütün hedeflerine ve değerlerine karşı kişinin duygusal tepkilerini ifade etmektedir.

Alanyazında örgütsel bağlılığın boyutlarına ilişkin çeşitli sınıflandırmalar yapılmıştır. O’Reilly ve Chatman (1986), bağlılığın boyutlarını; uyum, özdeşleşme, içselleştirme bağlılığı olmak üzere üç grupta incelemektedir. Modway ve arkadaşları (1979), bağlılığı davranışsal ve tutum bağlılığ şseklinde sınıflandırmaktadır. Weiner (1982) ise bağlılığ 1 araçsal ve moral bağlılık olarak kategorize etmektedir. Ancak eğitim literatüründe Meyer ve Allen'in boyutları ampirik çalışmalarda yaygın bir biçimde kullanılmıştır. Bu yazarlar örgütsel bağlılığın duygusal, devam ve normatif gibi üç boyutunun olduğunu belirtmektedirler. Duygusal bağlılık, çalışanların örgütsel değer, hedef ve amaçları benimsediklerine ilişkin hissettiği duygulardır. Devam bağlılığı, çalışanların örgütlerine ayırdıkları zaman ve gösterdikleri çabalara yönelik yaptırımları ve bunun karşılığında örgütte kalmanın zorunluluk olduğunu hissetmeleridir. Zira devam bağlılığı olan çalışanlar örgütlerinde ayrılmaları durumunda yeni iş bulma seçeneklerinin az olduğunu düşünmektedirler. Normatif bağlılık, çalışanların örgütte çalışmalarının kendileri için bir görev olduğu ve örgütün gerçek anlamda kendisine ihtiyaç duyduğunu düşünmekte ve işverenlerine minnettarlık duygusu beslemektedirler (Allen ve Meyer, 1993; Meyer ve Allen, 2000).

Uluslararası alanyazında okul müdürü liderlik davranışları ve öğretmenlerin örgütsel bağlılığı ilişkisine yönelik birçok araştırma yapılmıştır (Anderman, 1991; Hallinger, Hosseingholizadeh, Hashemi ve Kouhsari, 2018; Hulpia, Devos ve Van Keer, 2011; Ibrahim, Ghavifekr, Ling, Siraj ve Azeez, 2014; Ross ve Gray, 2006; Sun, 2004; Yu, Leithwood ve Jantzi, 2002). Benzer durum ulusal alanyazında da görülmektedir. Nitekim okul müdürlerinin liderlik stilleri (Akan, 2015; Bektaş, Çoğaltay ve Sökmen, 2014; Buluç, 2009), karizmatik özellikleri (Arabac1, 2014), etik liderlik davranışları (Ayık, Yücel ve Savaş, 2014; Madenoğlu, Uysal, Sarıer ve Banoğlu, 2014; Okçu, 2014; Uğurlu, Sancar ve Çınar, 2013), ruhsal liderlik (Bozkuş ve Gündüz, 2016), hizmetkâr liderlik (Cerit, 2010; Doğan ve Aslan, 2016), dönüşümcü liderlik (Çetin ve Aydın, 2012), destekleyici ve geliştirici liderlik öğretmenlerin bağlılıkları arasındaki ilişkiler araştırma konusu olmuştur (Erdoğan ve Kolamaz, 2011).

Tüm bu araştırmalarda incelenen okul müdürlerinin liderlik davranışları ile öğretmenlerin bağl1lıkları arasındaki ilişkilerinin yönü ve düzeyi, sıklıkla incelenen liderlik stilleri ve örgütsel bağlılık boyutlarının liderlik stilleri ile olan ilişkileri ve yordama düzeylerinin ayrıntılı bir biçimde incelenmesi önem arz etmektedir. Bununla birlikte araştırmalardaki ilişkisel bulguların bütüncül bir şekilde incelenmesi kuramsal alan yazına katkı sağlayacağı düşünülmektedir. Ayrıca elde edilen ortak sonuçlar ilerleyen dönemlerde konuya yönelik yapılacak araştırmalara bir yol gösterici rehber olacağı varsayılmaktadır. Diğer taraftan bir uygulayıcı olarak lider okul müdürünün öğretmenlerin okula olan bağlılıklarının artırılmasında söz konusu liderlik stillerinden hangisi/hangilerini sergilemeleri hususunda önemli bir veri sunacaktır. Bu bağlamada bu araştırmanın problem cümlesi şu şekildedir: "Okul müdürlerinin liderlik davranışları ile ögretmenlerin örgütsel bağlllıkları arasındaki ilişkileri inceleyen çalışmaların bulguları arasında ortak ortak noktalar var mıdır?”

\section{Yöntem}

Bu araştırma, Türkiye'de eğitim alanında okul yöneticilerinin liderlik davranışlarının öğretmenlerin örgütsel bağlılıkları arasındaki ilişkileri araştıran çalışmaları sistematik olarak incelemeyi amaçlamaktadır. Sistematik incelemelerde incelenen konuya yönelik bulgular, belli başlı kriterlere göre seçilmekte ve sentezlenmektedir (Victor, 2008). Belirlenen bir araştırma sorusunun belirli seçim kriterleri uygulandıktan sonra seçimler yapılması ve açık bir biçimde kanıtların bütüncül olarak değerlendirilmesini gerektirir. Nesnel olarak inceleme için sistematik bazı yollar izlenir (Higgins ve Green, 2011). Sistematik incelemelerde amaç belirlenmesi, kapsamın 
tespit edilmesi, bazı dâhil edilme ölçütlerinin kullanılması, veri tarama yöntemleri ve verilerin toplanması aşamalarından oluşmaktadır (Lunny, Brennan, McDonald ve McKenzie, 2016). Bu kapsamda sistematik incelemeler sırasıyla araştırma stratejsi, dâhil edilme kriteleri, tarama, verilerin toplanması ve tanımlanması, araştırmada kullanılan çalışmaların kalitelerinin ortaya konulması, bulguların sentezi bölümlerinden oluşmaktadır (Davies, Morriss ve Glazebrook, 2014; EPPI-Centre, 2006; Gough, 2007; Germain ve Cummings, 2010; Karaçam, 2013).

\section{Dahil Edilme Kriteleri}

Çalışmada ilk olarak incelenen çalışmaların 2000-2017 yıları arasında, ampirik, nicel, ulusal ve uluslararası hakemli dergilerde yayımlanmış olması ve üniversiteler dışındaki örgün eğitim kurumlarında yapılmış olması ölçütleri konulmuştur. Ayrıca araştırmaların Türkiye örnekleminde ve öğretmen algılarına göre çalışılmış olması ve bilimsel alanda saygın kabul edilen veri tabanlarındaki makalelerin yer alması gibi sınırlandırmalar yapılmıştır. Diğer taraftan tezler ve kuramsal çalışmalar araştırma dışında bırakılmıştır.

\section{Arama Stratejisi ve Veri Tabanları}

$\mathrm{Bu}$ çalışmanın verileri WOS, ERIC, EBSCO, SCOPUS, ULAKBİM dizinlerinin/veri tabanlarının yardımlarıyla sistematik derleme yöntemiyle toplanmıştır. Verilerin toplanması sürecinde Türkiye örnekleminde yapılmış araştırmalar şu arama terimleriyle araştırılmıştır: “örgütsel bağlllık, örgütsel bağlılık ve liderlik ilişkisi, organizational commitment and leadership” gibi farklı kombinasyonları içeren anahtar sözcükleri kullanılarak yapılmıştır. Bazı dergilerde ise kendi web sayfalarından araştırılmıştır. Aramalar Türkçe ve İngilizce dillerinde yapılmıştır.

\section{Tarama}

Araştırmaların tarama süreci sonunda veri tabanlarına girilen "örgütsel bağlllık” "örgütsel bağlllık ve liderlik ilişkisi”, "organizational commitment and leadership” anahtar sözcükleri girildikten sonra ilk aşamada toplam 197 makaleye ulaşılmıştır. Ulaşılan makalelerin veritabanlarına göre dağılımı şu şekildedir: SCOPUS 43 makale, ULAKBİM 50 makale, ERIC 40 makale Web of Science 58. İkinci aşamada çalışmaların öz kısımları detaylı biçimde okunmuştur. Üçüncü aşamada EPPI-Centre referans alınarak belirlenen ölçütlere göre, Türkiye örneklemi, kuramsal ve nitel çalışmalar, tekrar eden ve alan dışı çalışmalar inceleme dışı bırakıldıktan sonra geriye 29 makale kalmıştır. Ancak yöntemleri bakımından tekrar incelenen 29 makale arasında örneklem, model ve kapsam sorunlarından dolayı, 6 çalışma daha inceleme dışı bırakılmıştır. Böylece araştırma toplam 23 makale üzerinden yürütülmüştür.

\section{Araştırmaların Niteliklerinin Tespiti}

İncelenen 23 çalışmanın kalitesi EPPI-Centre (2006) çalışmasına ve Gough (2007) ve Davies vd., (2014) tarafından oluşturulan kanıtlara göre değerlendirilmiştir. Bu araştırmaların metodolojik niteliği ve konu başlığ1 ilgisinin bir bütün olarak değerlendirilmesi ise kanıtların gücünü ortaya koymaktadır. Bu bağlamda incelenen çalışmalardaki kanıtların araştırmaların iyi tasarlanması ve kullanılan ölçme araçlarının güvenirlik, geçerlik gibi çalışmaların yapılmış olması çalışmaları kanıt bakımından güçlü hale getirmektedir. Bununla birlikte metodoloji ve konuya göre seçilen makalelerin konu başlıklarının yakın olması incelenen çalışmalardaki kanıtları güçlendirmektedir. Bu bakımdan iki araştırmacı da kalite kontrol listesi hazırlayarak çalışmaların kalitelerine yöntemleri 1 ile 4 arasında değerler vererek çalışmaları değerlendirmişlerdir. Uyumsuzluk durumunda ise uzman görüşüne başvurulmuştur. Buradaki amaç güçlü ve zayıf kanıtları bir arada düzenli bir biçimde sunmak, bu çalışmayı daha güvenilir hale getirmektir. Bu aşamada incelenen 23 çalışmada kalite bakımından çok yetersiz olmadığına karar verilmiştir. Daha sonra elde edilen bulguların açık bir biçimde görülebilmesi için Microsoft Office Excel programı yardımıyla incelemeye alınan araştırmaların yazarları, konuları, yöntemleri, bulguları, güvenirlik ve bulguları verilmiştir (Ek 1). İncelenen çalışmalarda kullanılan ölçeklerin güvenirlik değerleri .65 ile .99 arasında değişmektedir. Çalışmaların büyük kısmında güvenirlik çalışmaları yeniden yapılmıştır. Bu kapsamda 18 çalışmada güvenirlik değerlerine yeniden bakılmış, 3 çalışmada rapor edilmemiş, 2 çalışmada ise ölçeği geliştirenlerin güvenirlik değerleri verilmiş ve 1 çalışmada ise hiçbir ölçeğin güvenirliği rapor edilmemiştir. Rapor edilmeyen çalışmalarda yöntem bölümü bir bütün olarak değerlendirilerek çalışmaya dâhil edilmişlerdir. Çalışmalarda örneklem büyüklükleri 200 ile 1112 arasındadır.

\section{Bulguların Sentezi}


Araştırmaların analizi sürecinde, makaleler tek tek okunmuş, kodlanmış, özetlenmiş ve kapsamlarına göre sınıflandırılmış̧ır. Örgütsel bağlılık ile ilişkili liderlik davranışlarına yonelik matrisler oluşturulmuştur. $\mathrm{Bu}$ matrislerde örgütsel bağll1ık ile ilişkili olan boyutlar tek tek tespit edilmiş ve temalar oluşturulmuştur. Daha sonra bu ilişkiler ve elde edilen temalara göre öncelikle ilişkileri gösteren tablo 1 oluşturulmuştur. Son aşamada ise örgütsel bağllıkla ilişkili olan liderlik davranışlarına ulaşılmış ve tablo 2 elde edilmiştir. Araştırmaya alınan makaleler kaynakçada inceleme alınan makaleler başlığı altında yer verilmiş̧ir.

\section{Bulgular}

\section{Liderlik davranışları ve örgütsel bağlılık}

Bu bölümde okul yöneticilerinin farklı liderlik davranışlarının örgütsel bağllıkla ilişkilerine dair bulgular verilmektedir. Öncelikle liderlik davranışlarının örgütsel bağlılık ile olan ilişkileri ortaya konulmuştur (Tablo 1). Sonraki bölümde ise örgütsel bağlılığa ilişkin alt boyutların liderlik uygulamaları ile olan ilişkileri incelenmiştir. $\mathrm{Bu}$ noktada amaç liderlik uygulamalarının örgütsel bağlılığın hangi özellikleri ile ilişkili olduğunu ortaya koymaktır.

\section{Liderlik davranışları ile örgütsel bağlılık arasındaki ilişkiler}

Dönüşümcü liderlik ile örgütsel bağglılığın ilişkili olduğunu gösteren beş adet çalışma bulunmaktadır (Akan ve Yalçın, 2015; Bektaş, Çoğaltay ve Sökmen, 2014; Buluç, 2009; Çetin ve Aydın, 2012; Kul ve Güçlü, 2010). Bu çalışmalardan iki tanesinde dönüşümcü liderliğin örgütsel bağlılığın bir yordayıcısı olduğu ortaya konulmuştur (Bektaş, Çoğaltay ve Sökmen, 2014; Kul ve Güçlü, 2010). Üç çalışmada dönüşümcü liderliğgin örgütsel bağlllık özelliklerinden özdeşleşme ve içselleştirme bağllllğı ile pozitif yönlü ilişkili olduğu ifade edilmiştir (Akan ve Yalçın, 2015; Bektaş, Çoğaltay ve Sökmen, 2014; Kul ve Güçlü, 2010). Bektaş, Çoğaltay ve Sökmen (2014) dönüşümcü, işlemsel ve serbestlik tanıyan liderlik arasında \%54 açıklama gücü ile örgütsel bağlllığı en yüksek açıklama gücüne dönüşümcü liderliğin sahip olduğu, onu \%15 ile işlemsel liderliğin izlediğini ve en düşük düzeyde açıklama gücüne ise $\% 1$ ile serbestlik tanıyan liderlik davranışları olduğunu belirtmişlerdir. Bunun yanında Kul ve Güçlü (2010) dönüşümsel liderliğin örgütsel bağl1lığı yordadığını, işlemsel liderliğin örgütsel bağlılığı yordamadığını ortaya koymuşlardır. Diğer taraftan Akan ve Yalçın (2015) işlemsel liderliğin özdeşme bağl1lığ i ile negatif yönde ilişkili olduğunu belirtmişlerdir. Buluç (2009) dönüşümcü liderlik özellikleriyle örgütsel bağl1lık arasında pozitif yönde ilişkiler bulunduğunu ve bu özelliklerden telkinle güdülemenin örgütsel bağlllı̆ıın tek anlamlı yordayıcısı olduğunu göstermiştir. Çetin ve Aydın (2012) çalışmalarında dönüşümcü liderlik özelliklerinden entelektüel uyarımın duygusal bağlılığı yordadığını ve devam bağlılığı ile pozitif yönde ilişkili olduğunu belirtmişlerdir. Arabacı, Alaoğlu ve Doğan (2014) çalışmalarında vizyon belirleme, çevresel duyarlık gösterme, kişisel risk üstlenme, iletişim sürdürme karizmatik liderlik özelliklerinin örgütsel bağlllık ile pozitif yönde ilişkili olduğunu belirmişlerdir. Buluç (2009)'un çalışmasıda idealleştirilmiş etki ve bireysel ilginin örgütsel bağl11ılıkla pozitif yönde ve anlamlı ilişkili olduğunu belirtmişlerdir.

Etik liderlik ile örgütsel bağllık arasında ilişki olduğunu ortaya koyan beş çalışma bulunmaktadır. Bu çalışmalardan dördünde etik liderliğin örgütsel bağlllığın anlamlı bir yordayıcısı olduğu tespit edilirken (Ayık, Yücel ve Savaş, 2014; Uğurlu, Sincar ve Çınar, 2013; Uğurlu ve Üstüner, 2011; Madenoğlu, Uysal, Sarıer ve Banoğlu, 2014), bir tanesinde ise anlamlı ve pozitif yönde ilişki olduğu ifade edilmiş̧ir (Okçu, 2014). Uğurlu ve Üstüner (2011) etik liderliğin örgütsel bağlllığı \%14 açıklama gücü, Uğurlu, Sincar ve Çınar (2013) ise \%6 açıklama gücü olduğunu ifade ederken, Madenoğlu, Uysal, Sarıer ve Banoğlu (2014) ise yüksek düzeyde bir yordama gücü olduğunu belirtmişlerdir $(\beta=.74)$. Bu çalışmalardaki liderlik özelliklerinin alt boyutlarının bağlılık ile ilişkisini ortaya koyan çalışmalardan Uğurlu ve Üstüner (2011) yöneticilerin etik liderlik davranışlarından sadece iklimsel etiğin öğretmenlerin okula bağlılığının anlamlı bir yordayıcısı olarak bulmuşlardır. Okçu (2014) etik liderlik davranışlarından sadece sorumluluk boyutunun özdeşleşme bağlılığını, hoşgörü boyutunun içselleştirme bağlllığının yordayıcısı olduğunu ortaya koymuştur. Ayık, Yücel ve Savaş (2014) ise yöneticilerin davranışsal etik davranışlarının devam bağlılığı ve duygusal bağlılı̆ın güçlü yordayıcıları olduğunu ve normatif bağllıkla pozitif yönde ve anlamlı düzeyde ilişkili olduğunu belirtmişlerdir. Bunun yanında karar vermede etiğin devam bağ lılığını ve normatif bağlılığı yordadığ ifade edilmiştir. Benzer biçimde Uğurlu, Sincar ve Çınar (2013) biçimde etik liderliğin duygusal bağlılığı ve normatif bağlılığı anlamlı biçimde yordadığını bulmuşlardır.

Okul müdürlerinin paylaşılan liderlik davranışlarının öğretmenlerin örgütsel bağlılık davranışlarını olumlu düzeyde yordadığına dair iki çalışmaya rastlanmıştır. Her iki çalışmada da paylaşılan liderlik öğretmenlerin duygusal ve normatif bağlılıkları ile olumlu yönde ilişkili olduğu bulunmuştur (Uslu ve Beycioğlu, 2013; Yetim, 18 
2016). Bu çalışmalardan Uslu ve Beycioğlu (2013) paylaşılan liderlik davranışlarının öğretmenlerin duygusal ve normatif bağlılıkları ile pozitif ve anlamlı ilişki verdiğini bulmuşlardır. Uslu ve Beycioğlu (2013) paylaşılan liderlik davranışlarının örgütsel bağlılığı \%27'lik bir açıklama gücüne sahip olduğunu belirtirken, Yetim (2016) paylaşılan liderlik ile örgütsel bağlılık arasında anlamlı ve pozitif bir ilişki olduğunu göstermiştir.

Okul müdürlerinin kültürel liderlik davranışların örgütsel bağlılıkla ilişkili olduğuna dair iki çalışmaya rastlanmıştır (Uygur ve Yıldırım, 2011; Teyfur, 2015). Bu çalışmalarda okul yöneticilerinin kültürel liderlik davranışlarının uyum bağlılığını azalttığı, özdeşleşme ve içselleştirme bağlılığını artırdığını ortaya konulmuştur. Kültürel liderlik davranışlarının örgütsel bağlılık özelliklerini \%9 ile \%32 arasında açıkladığı ve kültürel liderlik davranışlarını özdeşleşme bağlılığı ve içselleştirme bağlılığını orta düzeylerde açıklama gücüne sahip olduğu görülmüştür. Bunun yanında bu çalışmalarda kültürel liderlik davranışları uyum bağlılığı ile anlamlı ve ters yönde ilişkili olduğu \%9 ile \%14 arasıda bir açıklama gücünün olduğu tespit edilmiştir.

Okul müdürlerinin hizmetkar liderlik davranışları öğretmenlerin bağlılıklarının yordayıcısıdır (Cerit, 2010; Doğan ve Aslan, 2016). Cerit (2010) çalışmasında hizmetkar liderlik davranışlarından bireylere değer verme, insanları geliştirme, topluluk oluşturma, otantik davranma, liderliği geliştirme, liderliği paylaşma ile örgütsel bağlılık ile pozitif ve anlamlı düzeyde ilişkiler verdiğini ifade etmiştir. Bu iki çalışmada hizmetkar liderliğin örgütsel bağlılığ1 \%61 ve \%69 düzeyinde bir açıklama gücüne sahip olduğu görülmüştür. Bunun yanında Doğan ve Aslan hizmetkar liderliğin normatif, duygusal ve devam bağlılığını \%43 ile \%49 arasında açıkladığını ifade etmişlerdir.

Çokluk ve Yılmaz (2010) destekleyici liderliğin örgütsel bağlılığı pozitif yönde yordadığı, emredici liderliğin ise örgütsel bağlığı azalttığını belirtmişlerdir. Benzer biçimde Yaman ve Özer (2015) öğretmenleri geliştiren ve destekleyen davranışların öğretmenlerin örgütsel bağlılıkları ile pozitif ve anlamlı ilişkiler verdiğini ifade etmişlerdir. Şama ve Kolamaz (2011) geliştirici ve destekleyici liderlik davranışları ile uyum bağlılığın azaldığını, özdeşleşme bağlılığı ve içselleştirme bağlılığının arttığını göstermişlerdir.

Bozkuş ve Gündüz (2016) ruhsal liderlik davranışlarının öğretmenlerde bağlılığı artırdığı, duygusal ve normatif bağlılığ1 yüksek düzeylerde yordadığı görülmüştür.

İki farklı çalışmada değişim ve yetenek yönetimi davranışlarının öğretmenlerin örgütsel bağlılığı ile ilişkili olduğu ortaya konulmuştur. Çağrıcı ve Savaş (2016) okulda yöneticilerin değişimi kabul ettirme ve değişim davranışlarına yönelik davranışlarını gösterme düzeyleri arttıkça öğretmenlerin örgütsel bağlılıkları arttığını ifade etmiştir. Diğer taraftan Aytaç (2015) okul müdürlerinin yetenek yönetimi liderlik davranışlarının örgütsel bağlılığı yordadığını göstermiştir. Bunun yanında aynı çalışmada yetenek yönetimi özelliklerinden stratejik yetenek ve başkalarıyla birlikte çalışmanın örgütsel bağlılığın önemli yordayıcıları olduğu görülmüş̧ür.

Tablo 1. Örgütsel Bağlılık ya da Alt Boyutlarını Yordayan Liderlik Yaklaşımları ve Modelleri

\begin{tabular}{ll}
\hline Yordayııı liderlik yaklaşımları ve modelleri & Kaynaklar \\
\hline Değişim liderliği & Çağrıcı ve Savaş (2016) \\
\hline $\begin{array}{l}\text { Başkalarıyla birlikte çalışma, } \\
\text { Stratejik yetenek }\end{array}$ & Aytaç (2015) \\
\hline Destekleyici ve geliştirici liderlik & Çokluk ve Yılmaz (2010) \\
\cline { 2 - 2 } & Şama ve Kolamaz (2011) \\
\hline Telkinle güdüleme & Buluç (2009) \\
\hline Bireysel ilgi, entelektüel uyarım & Çetin ve Aydın (2012) \\
\hline Dönüşümcü liderlik & Kul ve Gü̧̧lü (2010) \\
\cline { 2 - 2 } & Bektaş, Çoğaltay ve Sökmen (2014) \\
\hline Davranışsal etik, karar vermede etik & Akan ve Yalçın (2015) \\
\hline Etik davranışlar & Ayı, Yücel ve Savaş (2014) \\
\hline İklimsel etik & Uğurlu, Sincar ve Çınar (2013) \\
\hline Etik liderlik davranışları & Uğurlu ve Üstüner (2011) \\
\hline Sorumluluk, hoşgörü & Madenoğlu, Uysal, Sarır ve Banoğlu \\
\hline $\begin{array}{l}\text { Bireylere değer verme, insanları geliştirme, otantik } \\
\text { davranma }\end{array}$ & (2014) \\
\hline
\end{tabular}




\begin{tabular}{ll}
\hline Hizmetkar liderlik & Doğan ve Aslan (2016) \\
\hline Kültürel liderlik & Uygur ve Yıldırım (2011) \\
\cline { 2 - 2 } & Teyfur (2015) \\
\hline Paylaşılan liderlik & Uslu ve Beycioğlu (2013) \\
\hline Ruhsal liderlik & Bozkuş ve Gündüz (2016) \\
\hline $\begin{array}{l}\text { Örgütsel bağlılıkla ilişkili liderlik yaklaşımları ve } \\
\text { modelleri }\end{array}$ & Kaynaklar \\
\hline Destekleyici ve geliştirici liderlik & Yaman ve Özer (2015) \\
\hline Dönüşümcü liderlik & Buluç (2009) \\
\hline Dönüşümcü liderlik & Çetin ve Aydın (2012) \\
\hline Dönüsümcü liderlik & Akan ve Yalçın (2015) \\
\hline Karizmatik & Arabacı, Alanoğlu ve Doğan (2014) \\
\hline Etik liderlik & Okçu (2014) \\
\hline Öğretim liderliği & Yaman ve Özer (2015) \\
\hline Paylaşlan liderlik & Yetim (2016) \\
\hline
\end{tabular}

\section{Liderlik Davranışları ile Örgütsel Bağgılığın Alt Boyutları Arasındaki İlişkiler}

\section{Uyum Bağlıı̆ğ ile İlgili İlişkiler}

Beş farklı çalışmada uyum bağlılı̆ı ile farklı liderlik davranışları arasında anlamlı ve ters yönde ilişki olduğuna dair bulgular bulunmaktadır (Kul ve Güçlü, 2010; Okçu, 2014; Şama ve Kolamaz, 2011; Teyfur, 2015; Uygur ve Yıldırım, 2011). Bu çalışmalarda destekleyici liderlik, kültürel liderlik, etik liderlik boyutları olan hoşgörü, adalet, sorumluluk, dürüstlük, demokratik davranışlar ile uyum bağlllığı ve dönüşümcü liderlik ile uyum bağlllığı arasında anlamlı ve ters yönde ilişkili olduğu bulunmuştur. Bunların yanında Bektaş, Çoğaltay ve Sökmen (2014) çalışmasında serbestlik tanıyan liderlik ve sürdürümcü liderlik ile uyum bağlılığı pozitif yönde ve anlamlı olarak ilişkili bulunmuştur. Bu çalışmaların aksine Akan ve Yalçın (2015) çalışmasında dönüşümcü ve serbest bırakıcı liderlik ile uyum bağl1lığı arasında anlamlı bir ilişki olmadığını belirtmiştir. Uyum bağlılığının azalması öğretmenlerin yüzeysel davranışlarının azaldığını ve okullarına daha güçlü bağlandıklarını göstermektedir.

\section{Devam Bağılığı ile İlgili İlişkiler}

İncelenen yedi farklı çalışmada devam bağlılığı ile liderlikte farklı davranışların anlamlı ve pozitif yönde ilişkileri olduğuna dair bulgular bulunmaktadır (Arabacı, Alanoğlu ve Doğan, 2014; Aytaç, 2015; Bozkuş ve Gündüz, 2016; Çetin ve Aydın, 2012; Çokluk ve Yılmaz, 2010; Doğan ve Aslan, 2016). Destekleyici liderlik, hizmetkar liderlik ruhsal liderlik, yetenek yönetimi liderliği boyutlarından stratejik yetenek ve başaklarıyla birlikte çalışma ile devam bağlllığı arasında ve karizmatik liderlik, karar vermede etik ve dönüşümcü liderlik boyutlarından ilham verici motivasyon, bireysel ilgi ve entelektüel uyarım ile devam bağlılığı arasında anlamlı ve pozitif yönde ilişkiler olduğu bulunmuştur. Bunlarla birlikte bu bulguların aksine üç çalışmada ise devam bağlılığı ile liderlik davranışları arasında bir ilişki olmadığı görülmektedir. Bunlar öğretim liderliği, paylaşılan liderlik ve etik liderliktir (Uslu ve Beycioğlu, 2013; Uğurlu, Sincar ve Çınar, 2013; Yaman ve Özer, 2015). Devam bağlllı̆ğ bazı zorunluluklardan dolayı okula bağlanma olduğundan, liderlik davranışlarının bu zorunlu bağlılığı güçlendirdiği ifade edilebilir.

\section{Özdeşleşme veya İçselleştirme Bağılı̆̆ı}

İncelenen yedi farklı çalışmada farklı liderlik davranışların öğretmenlerin özdeşleşme ve içleştirme bağlılığı ile anlamlı ve pozitif yönlü ilişkili olduğuna dair bulgular bulunmaktadır. Bunlar destekleyici liderlik, kültürel liderlik, etik liderlik, dönüşümcü liderliktir. (Bektaş, Çoğaltay ve Sökmen, 2014; Kul ve Güçlü, 2010; Okçu, 2014; Şama ve Kolamaz, 2011; Teyfur, 2015; Uygur ve Yıldırım, 2011). Bunların yanında işlemsel liderlik ile ilgili iki çalışma içselleştirme bağlılığı ile anlamlı ve pozitif ilişki olduğunu göstermektedir (Bektaş, Çoğaltay ve Sökmen, 2014; Kul ve Güçlü, 2010). İki farklı çalışmada ise sürdürümcü liderlik ile özdeşleşme arasındaki ilişkiye dair çelişkili bulgular bulunmaktadır (Bektaş, Çoğaltay ve Sökmen, 2014; Akan ve Yalçın, 2015). 


\section{Duygusal ve Normatif Bağlılık}

İncelenen altı farklı çalışmada farklı liderlik davranışlarının duygusal ve normatif bağlılıkla pozitif ve anlamlı ilişkileri olduğuna dair bulgular bulunmaktadır (Arabacı, Alanoğlu ve Doğan, 2014; Ayık, Yücel ve Savaş, 2014; Bozkuş ve Gündüz, 2016; Doğan ve Aslan, 2016; Uğurlu, Sincar ve Çınar, 2013; Uslu ve Beycioğlu, 2013). Bunlar hizmetkar liderlik, paylaşılan liderlik, ruhsal liderlik, karizmatik liderlik, etik liderlik davranışlarıdır. Bunun yanında bireysel ilgi ve entelektüel uyarım ile duygusal bağlllık arasında pozitif ve anlamlı ilişki, dönüşümcü liderlik ile normatif bağlılık arasında pozitif ve anlamlı ilişki olduğu bulunmuştur (Çetin ve Aydın, 2012). Çokluk ve Yılmaz (2010) destekleyici liderlik ile duygusal bağlılık arasında pozitif ve anlamlı, emredici liderlik ile duygusal bağlılık arasında negatif ve anlamlı ilişki bulmuşlardır.

Farklı liderlik davranışlarının örgütsel bağlılık alt boyutlarıyla olan ilişkiler karşılıklı nedensellik bağlamında değerlendirilmektedir. Çalışmalardaki ilişkileri ortaya koyan bulgular neden sonuç ilişkisi ortaya koymamakla birlikte bazı tahminler yapmaya izin vermektedir. Bu bağlamda dair bazı sonuçlara ulaşılabilir. Okul yöneticilerinin bireylerin desteklendiği, ortak değerlere vurgu yapılan, işbirliği ve iletişimin güçlü olduğu ortamlarda öğretmenlerin uyum bağllıkları azalmaktadır, Diğer bir ifadeyle öğretmenler daha az yüzeysel davranışlar göstermektedirler. Bunun yanında öğretmenlerin devam bağlılıkları artmaktadır. Yöneticilerin bu liderlik davranışları öğretmenleri kurumlarında kalmaya zorlamaktadır. Bununla birlikte okul yöneticilerinin bireysel ilgileri, ortak vizyon ve amaçlar oluşturmaya çalışmaları, iş birliği ve güven kültürünü desteklemeleri ve rol model olmalarıyla birlikte öğretmenlerin özdeşleşme, içselleştirme, duygu ve normatif bağllıklarının artacağı ifade edilebilir.

Tablo 2. Öğretmenlerin Örgütsel Bağlılığını Yordayan Lider Müdür Davranışları

\begin{tabular}{|c|c|}
\hline Liderlik davranışları & Kaynaklar \\
\hline Ortak amaç ve vizyon oluşturma & $\begin{array}{l}\text { Çağricı ve Savaş (2016), Buluç (2009), Kul ve Güçlü (2010), Bektaş, } \\
\text { Coğaltay ve Sökmen (2014), Akan ve Yalçın (2015), Doğan ve Aslan } \\
\text { (2016) Cerit (2010), Bozkuş ve Gündüz (2016). }\end{array}$ \\
\hline İşbirliği kültürü & $\begin{array}{l}\text { Aytaç (2015), Okçu (2014), Ayık, Yücel ve Savaş (2014,) Cerit (2010), } \\
\text { Doğan ve Aslan (2016) }\end{array}$ \\
\hline İletişim ve etkileşimi artırma & $\begin{array}{l}\text { Buluç (2009), Şama ve Kolamaz (2011), Çokluk ve Yılmaz (2010), } \\
\text { Okçu (2014), Cerit (2010), Uslu ve Beycioğlu (2013) }\end{array}$ \\
\hline $\begin{array}{l}\text { Bireysel ilgi gösterme ve değer } \\
\text { verme }\end{array}$ & $\begin{array}{l}\text { Buluç (2009), Çetin ve Aydın (2012), Kul ve Güçlü (2010), Bektaş, } \\
\text { Çoğaltay ve Sökmen (2014), Akan ve Yalçın (2015), Cerit (2010), } \\
\text { Doğan ve Aslan (2016) }\end{array}$ \\
\hline $\begin{array}{l}\text { Destekleyici ve geliştirici } \\
\text { davranışlar gösterme }\end{array}$ & $\begin{array}{l}\text { Çokluk ve Y1lmaz (2010), Şama ve Kolamaz (2011), Cerit (2010), } \\
\text { Doğan ve Aslan (2016) }\end{array}$ \\
\hline $\begin{array}{l}\text { Adalet, saygı ve güven temelli } \\
\text { çalışma kültürü oluşturma }\end{array}$ & $\begin{array}{l}\text { Aylk, Yücel ve Savaş (2014), Uğurlu, Sincar ve Çınar (2013), Uğurlu } \\
\text { ve Üstüner (2011), Madenoğlu, Uysal, Sarıer ve Banoğlu (2014), Okçu } \\
\text { (2014) Cerit (2010), Teyfur (2015), Uğurlu ve Üstüner (2011) }\end{array}$ \\
\hline $\begin{array}{l}\text { Kontrol ve sorumluluğu çalışanlar } \\
\text { arasında paylaşma }\end{array}$ & Uslu ve Beycioğlu (2013), Yetim (2016) \\
\hline $\begin{array}{l}\text { Okulda ortak değer ve semboller } \\
\text { oluşturma }\end{array}$ & $\begin{array}{l}\text { Buluç (2009), Çetin ve Aydın (2012), Uygur ve Yıldırım (2011), Bozkuş } \\
\text { ve Gündüz (2016), Uğurlu ve Üstüner (2011) }\end{array}$ \\
\hline Değişimi yönetme ve sürdürme & $\begin{array}{l}\text { Çağricı ve Savaş (2016), Çetin ve Aydın (2012), Buluç (2009), Kul ve } \\
\text { Güçlü (2010), Bektaş, Çoğaltay ve Sökmen (2014), Akan ve Yalçın } \\
\text { (2015) }\end{array}$ \\
\hline
\end{tabular}

Bütün bu araştırma bulguları bir arada düşünüldüğünde öğretmenlerin örgütsel bağlllıklarını üzerinde etkili olabilecek bazı liderlik davranışları ve davranışları şu şekilde ifade edilebilir (Tablo 2): okulda ortak amaç ve vizyon oluşturma, işbirliği kültürü, iletişim ve etkileşimi artırma, bireylere ilgi gösterme ve değer verme, destekleyici ve geliştirici davranışlar gösterme, okulda adalet, saygı ve güven temelli çalışma kültürü oluşturma, kontrol ve sorumluluğu paylaşma, okulda değişimi yönetme ve sürdürmedir. 


\section{Tartışma ve Sonuç}

$\mathrm{Bu}$ araştırmada alanyazında belirli kriterlere göre seçilen çalışmalarda okul yöneticilerinin hangi tür liderlik davranışlarının öğretmenlerin örgütsel bağlılıkları üzerinde potansiyel olarak etkili olduğunu ortaya koymak amaçlanmıştır. Bu bağlamda incelenen araştırmalardaki ortak bulgulara göre, okul müdürlerinin farklı türlerdeki liderlik davranışlarını daha fazla sergilemeleriyle birlikte öğretmenlerin okullarına olan bağlılıklarının arttığı sonucuna ulaşılmıştır. Mathieu ve Zazac'ın (1990) örgütsel bağlılığın kökenlerine ve sonuçlarına ilişkin metaanaliz çalışmasında, örgütsel ve kişisel özelliklerin, lider-grup ilişkilerinin örgütsel bağlılığın temelini oluşturduğu kanıtı bu sonucu destekler niteliktedir. Benzer şekilde Cowden, Cummings ve Profetto-Mcgrath (2011) yöneticilerin liderlik davranışlarıyla hemşirelerin işten kalma niyeti ve bağlılıkları arasındaki ilişkiye yönelik sistematik incelemesinde, dönüşümcü liderlik, destekleyici çalışma ortamlarının hemşirelerin işte kalma niyetini ve bağlılığını artırdığını belirlemiş̧lerdir. Bununla birlikte araştırmada ilişkisel liderliğin hemşirelerin göreve devam etme niyetlerini, çalışma ortamlarının kalitesini ve bağlılıklarını artırdığını saptanmıştır. Buna karşın Choi ve Tang (2009), sistematik derleme çalışmalarında öğretmenlerin bağlılı̆̆ını azaltan faktörler arasında okul müdürlerinin özerklik tanımaması, işbirliğinin zayıflığı, öğrenme firsatlarının ve karara katılımın sağlanmaması gibi durumları saymıştır. Bu sonuç okul liderlerinin öğretmenlerin okullarına bağlılıkları üzerinde etkili olduğunu göstermektedir.

Araştırmalarda yaygın olarak çalışılan konular; liderlik davranışları okulda ortak amaç ve vizyon oluşturma, iş birliği kültürü oluşturma, iletişim ve etkileşimi artırma, bireylere ilgi gösterme ve değer verme, destekleyici ve geliştirici davranışlar gösterme, okulda adalet, saygı ve güven temelli çalışma kültürü oluşturma, kontrol ve sorumluluğu paylaşma, okulda değişimi yönetme ve sürdürme olarak tespit edilmiştir. Bu bağlamda bu değişkenler bir bütün olarak düşünüldüğünde insan odaklı davranışların örgütsel bağl1lığı güçlendirme potansiyeli taşıdığ ifade edilebilir. Diğer taraftan bu çalışmada öğretmenlerin örgütsel bağlılıkları ile derecesine göre sırasıyla dönüşümcü liderlik, hizmetkâr liderlik ve etik liderlik davranışlarının araştırmada ele alınan diğer liderlik yaklaşımlarına göre daha güçlü ilişkiler verdiği ve önemli yordayıcıları olduğu görülmüştür. Meyer, Stanley, Herscovitch ve Topolnytsky (2002) örgütsel bağlılığın boyutlarından duygusal, devam ve normatif bağlılıklarının sonuçları ve öncülleri üzerine yaptıkları meta analiz çalışmasında da örgütsel bağlılık ile örgütsel adalet ve dönüşümcü liderlik arasında güçlü ilişkilerin olduğunu tespit etmişlerdir. Cummings ve arkadaşlarının (2010) sistematik derleme çalışmalarında yöneticilerin ilişkisel ve dönüşümsel liderlik becerilerinin sağlık kuruluşlarında çalışan hemşirelerin iş birliği içerisinde çalışmalarını, bağlılıklarını ve motivasyonlarını olumlu yönde etkilediği sonucuna ulaşılmıştır. Jackson, Meyer ve Wang (2013) liderlik, bağlılık ve kültür arasındaki ilişkileri inceledikleri çalışmalarında duygusal ve normatif bağlılığın dönüşümcü ve karizmatik liderlik ile pozitif ilişkili, serbest bırakıcı liderlik ile negatif ilişkili olduğunu saptamışlardır.

\section{Okul Yöneticilerine Yönelik Çıkarımlar}

Okul yöneticilerinin öğretmenlerle birebir ilişkiler kurmaları, çalışanlarla biz duygusu oluşturmaları ve okul kadrosunun güvenini kazanmalarının öğretmenlerin bağlılıklarını artıracağı söylenebilir. Bu bakımdan kimsenin dışlanmadığı, herkesin değer gördüğünü hissettiği işbirliği, destek ve güvenin olduğu bir okul kültürü anlayışının geliştirilmesinin önemlidir. Dolayısıyla okul müdürlerinin liderlik davranışlarını geliştirme ve bu paralelde eğitimler almaları nitelikli ilişkiler geliştirmeleri bakımından önerilebilir.

Bu çalışmada okul yöneticilerinin ilişki odaklı liderlik davranışlarının öğretmen örgütsel bağlılığını potansiyel olarak geliştirme gücüne sahip olduğunu ortaya koymuştur. Bu bağlamda teoriye katkı sağladığ düşünülmektedir. Bununla birlikte bu çalışmada bazı sınırlıklar bulunmaktadır. Öncelikle çalışma yalnızca Türkiye örneklemi incelenmiştir. Çalışmalar ilişkisel olduğundan dolayı neden sonuç bağlamında yorumları yapmayı zorlaştırmaktadır ve genellenebilirliği zayıflatmaktadır. Bunun yanında araştırma veri tabanlarından ulaşılabilen çalışmalarla sınırlıdır.

Okul müdürlerinin liderlik davranışlarındaki farklı örüntülerin öğretmenlerin bağlılıkları ile ilişkili olduğunu birçok çalışma göstermektedir. Bu bağlamda liderlik ve bağlılık arasındaki ilişkiyi güçlendirecek aracı değişkenlerle çalışmalar genişletilebilir. Diğer taraftan neden-sonuç ilişkilerini test eden araştırmalar planlanabilir. Diğer taraftan araştırma tezlerle yinelenebilir. Uluslararası alanyazın incelenerek çalışmalar genişletilebilir. 
Cansoy, R. \& Polatcam, M. (2019). The Relationship Between School Principals' Leadership and Teachers' Organisational Commitment: A Systematic Review. Bartin University Journal of Faculty of Education, 8(1), 1-

\begin{tabular}{|c|c|c|c|c|c|c|c|}
\hline No & Yazarlar & Katilımcilar & Ölçme araçları- boyutlar & $\begin{array}{l}\text { Güvenirlik } \\
\text { Cronbach } \alpha\end{array}$ & $\begin{array}{l}\text { Analiz } \\
\text { yöntemi }\end{array}$ & Bulgular & İstatistik \\
\hline 1 & Çağrıcı ve Savaş (2016) & $\begin{array}{l}252 \\
\text { ilköğretim } \\
\text { öğretmeni }\end{array}$ & $\begin{array}{l}\text { Değisisim liderliği } \\
\quad \text { Liderin değisisimi kabul ettirme davranışı } \\
\text { Liderin değisiim uygulamaları davranışı } \\
\text { Örgütsel bağll11k }\end{array}$ & .95 & $\begin{array}{l}\text { Korelasyon } \\
\text { Regresyon }\end{array}$ & $\begin{array}{l}\text { Okul müdürlerinin değisisim liderliği davranışları ögrretmenlerin } \\
\text { örgütsel bağıllığııı yordamaktadır. }\end{array}$ & $\begin{array}{l}r=.42 \\
R^{2}=.225 \\
\beta=.431\end{array}$ \\
\hline 2 & Şama ve Kolamaz (2011) & $\begin{array}{l}180 \\
\text { ilköğretim ve } \\
\text { ortaöğretim } \\
\text { ögretmeni }\end{array}$ & $\begin{array}{l}\text { Destekleyici ve geliştirici liderlik yaklaşımları } \\
\text { Örgütsel bağılıık } \\
\text { Uyum, Özdeşleşme, İçselleştirme }\end{array}$ & $\begin{array}{l}.92 \text { (orijinal ölçek } \\
\text { rapor edilmiş). } \\
.79 \text { ile } .93 \text { arası } \\
\text { rapor edilmiştir. }\end{array}$ & $\begin{array}{l}\text { Korelasyon } \\
\text { Regresyon }\end{array}$ & $\begin{array}{l}\text { Okul yöneticilerinin destekleyici liderlik ve gelistiricici liderlik } \\
\text { ozzellikleri uyum bağglığı ile negatif yönde iliskilidir. } \\
\text { Özdeşleşme bağllığını destekleyici liderlik ve geliştirici } \\
\text { liderlik yordamaktadır. } \\
\text { İcselleştirme bağllığını destekleyici liderlik ve geliştirici } \\
\text { liderlik yordamaktadır. }\end{array}$ & $\begin{array}{l}\mathrm{r}=-.27 \\
\mathrm{r}=-.30 \\
R^{2}=.45 \\
\mathrm{r}=.66 / \mathrm{r}=.63 \\
R^{2}=.30 \\
\mathrm{r}=.53 / \mathrm{r}=.53\end{array}$ \\
\hline 3 & Çokluk ve Yilmaz (2010) & $\begin{array}{l}200 \quad \text { ilkokul } \\
\text { öğretmeni }\end{array}$ & $\begin{array}{l}\text { Liderlik davranışları } \\
\text { Yönlendirici liderlik davranışları } \\
\text { Emredici liderlik davranışları } \\
\text { Örgütsel bağllık } \\
\text { Duygusal bağllık, Sürekli bağılık }\end{array}$ & Rapor edilmemiş. & $\begin{array}{l}\text { Korelasyon } \\
\text { Regresyon }\end{array}$ & 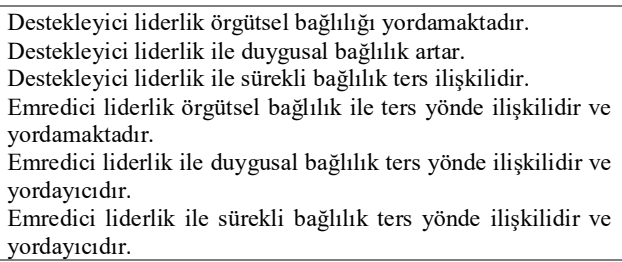 & $\begin{array}{l}\left(\mathrm{R}^{2}=.24\right) \\
\left(\mathrm{R}^{2}=.23\right) \\
\left(\mathrm{R}^{2}=.09\right) \\
\left(\mathrm{R}^{2}=.22\right) \\
\left(\mathrm{R}^{2}=.23\right) \\
\left(\mathrm{R}^{2}=.07\right)\end{array}$ \\
\hline 4 & Cerit, Y. (2010) & $\begin{array}{l}563 \quad \text { ilkokul } \\
\text { öğretmeni }\end{array}$ & $\begin{array}{l}\text { Hizmetkar liderlik } \\
\text { Bireylere değer verme, İnsanları geliştirme } \\
\text { Topluluk oluşturma, Otantik davranma } \\
\text { Liderliği geliştirme, Liderliği paylaşma } \\
\text { Orgütsel bağllık }\end{array}$ & $\begin{array}{l}.98 \\
.88-.92 \\
.91\end{array}$ & $\begin{array}{l}\text { Korelasyon } \\
\text { Regresyon }\end{array}$ & 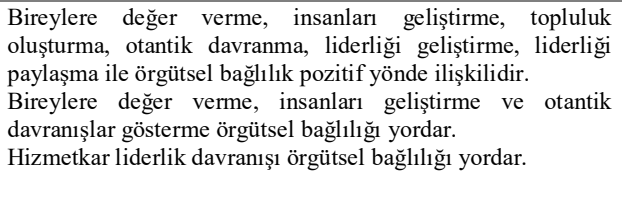 & $\begin{array}{l}\beta=.20, \quad \beta=.47, \\
\beta=.45 \\
\left(\mathrm{R}^{2}=.69\right)\end{array}$ \\
\hline 5 & Doğan ve Aslan (2016) & $\begin{array}{l}336 \text { özel } \\
\text { eğitim ve } \\
\text { uygulama ve } \\
\text { bilim sanat } \\
\text { merkezi } \\
\text { oggretmenleri }\end{array}$ & $\begin{array}{l}\text { Hizmetkar liderlik } \\
\text { Örgütsel adanmışlık } \\
\text { Duygusal bağll1k, Devam bağl1lı̆ı̆ } \\
\text { Normatif bağll1lk }\end{array}$ & $\begin{array}{l}.98 \\
.85 \\
.93-89\end{array}$ & $\begin{array}{l}\text { Tanımlayıc1 } \\
\text { Korelasyon } \\
\text { Regresyon }\end{array}$ & 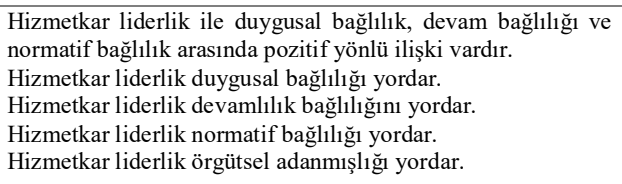 & $\begin{array}{l}\mathrm{r}=.66-.70 \\
\left(\mathrm{R}^{2}=.43\right) \\
\left(\mathrm{R}^{2}=.44\right) \\
\left(\mathrm{R}^{2}=.49\right) \\
\left(\mathrm{R}^{2}=.61\right)\end{array}$ \\
\hline 6 & Yaman ve Özer (2015) & $\begin{array}{l}378 \text { ortaokul } \\
\text { öğretmeni }\end{array}$ & $\begin{array}{l}\text { Öğretim liderliği } \\
\text { Örgütsel bağlll1k }\end{array}$ & .97 & $\begin{array}{l}\text { Tanımlayıc1 } \\
\text { Korelasyon }\end{array}$ & $\begin{array}{l}\text { Öğretim liderliğgi davranısları öğretmenlerin örgütsel bağllık } \\
\text { davranısları ile pozitif yönde iliskkilidir. } \\
\text { Öğretim liderliği ile tek anlamlı ilişki veren örgütsel bağlllık } \\
\text { boyutu normatif bağıllıktır. }\end{array}$ & $\begin{array}{l}r=.14 \\
r=.24 \\
r=.19\end{array}$ \\
\hline
\end{tabular}


Cansoy ve Polatcan

\begin{tabular}{|c|c|c|c|c|c|c|c|}
\hline & & & & & & $\begin{array}{l}\text { Öğretmenlerin desteklenmesi ve geliştirilmesi davranı̧ı } \\
\text { oggretmen bağllığını en yüksek düzeyde ilişkili olan ögretim } \\
\text { liderliği boyutudur. }\end{array}$ & \\
\hline \multicolumn{8}{|c|}{ Ek 1. Devamı } \\
\hline \multirow[t]{2}{*}{7} & Uygur ve Yildirrm (2011) & $\begin{array}{l}402 \\
\text { ilköğretim }\end{array}$ & $\begin{array}{l}\text { Külttürel liderlik } \\
\text { Örgütsel bağllık }\end{array}$ & .94 & $\begin{array}{l}\text { Tanımlayıcı } \\
\text { Korelasyon }\end{array}$ & $\begin{array}{l}\text { Okul müdürlerinin kültürel liderlik rolleri ile uyum bağılıı̆ı } \\
\text { ters yönde ilişkilidir ve yordanmaktadır. }\end{array}$ & \\
\hline & & ögretmeni & Uyum, Özdeşleşme, İçselleştirme & $\begin{array}{l}.79-.93 \text { (orijinal } \\
\text { calışmadaki } \\
\text { degerler) }\end{array}$ & & $\begin{array}{l}\text { Okul müdürlerinin kültürel liderlik rolleri ile özdeşlessme ve } \\
\text { içselleştirme ile pozitif yönde ilişkilidir ve yordayıcıldr. }\end{array}$ & $\begin{array}{l}\left(\mathrm{r}^{2}=.32\right) \\
\left(\mathrm{r}^{2}=.24\right)\end{array}$ \\
\hline \multirow[t]{2}{*}{8} & Teyfur (2015) & $\begin{array}{l}530 \text { ortaokul } \\
\text { öğretmeni }\end{array}$ & $\begin{array}{l}\text { Külttürel liderlik } \\
\text { Örgütsel bağllık }\end{array}$ & .92 & $\begin{array}{l}\text { Tanımlayıc1 } \\
\text { Nedensel }\end{array}$ & $\begin{array}{l}\text { Okul müdürlerinin kültürel liderlik rolleri ile uyum bağllığı } \\
\text { ters yönde ilişkilidir ve yordanmaktadır. }\end{array}$ & \\
\hline & & & Uyum, Özdeşleşme, İçselleştirme & $\begin{array}{l}.79-.93 \text { (orijinal } \\
\text { çalşmadaki } \\
\text { degerler) }\end{array}$ & $\begin{array}{l}\text { karşılaş̧trma } \\
\text { Korelasyon }\end{array}$ & $\begin{array}{l}\text { Okul müdürlerinin kültürel liderlik rolleri ile özdeşlessme ve } \\
\text { içselleştirme ile pozitif yönde ilişkilidir ve yordayıcıldır. }\end{array}$ & $\begin{array}{l}\left(\mathrm{r}^{2}=.15\right) \\
\left(\mathrm{r}^{2}=.21\right)\end{array}$ \\
\hline \multirow[t]{2}{*}{9} & Uslu ve Beycioğlu (2013) & $\begin{array}{l}324 \\
\text { ilköğretim } \\
\text { ögretmeni }\end{array}$ & $\begin{array}{l}\text { Paylaşlan liderlik } \\
\text { Örgütsel Bağll11k } \\
\text { Duygusal bağll11k, Devam bağl1lı̆ı̆ }\end{array}$ & .92 & $\begin{array}{l}\text { Tanımlayıcı } \\
\text { Nedensel } \\
\text { karşılaşırma }\end{array}$ & $\begin{array}{l}\text { Okul müdürlerinin paylaşılan liderlik rolleri örgütsel bağlllık } \\
\text { davranışı ile pozitif yönde iliş̧kilidir ve paylaşlan liderlik } \\
\text { açıklayıııdır. }\end{array}$ & $\left(\mathrm{r}^{2}=.27\right)$ \\
\hline & & & Normatif bağl1lık & .77 & Korelasyon & $\begin{array}{l}\text { Duygusal bağgllık ve normatif bağll1ık paylaşılan liderlik ile } \\
\text { pozitif yönde ilişkilidir. }\end{array}$ & $\begin{array}{l}\mathrm{r}=.52 \\
\mathrm{r}=.53\end{array}$ \\
\hline 10 & Yetim (2016) & $\begin{array}{l}473 \\
\text { ilköğretim } \\
\text { oggretmeni }\end{array}$ & $\begin{array}{l}\text { Dağıtımcı liderlik } \\
\text { Örgütsel bağll1ık }\end{array}$ & Rapor edilmemiş & Korelasyonel & $\begin{array}{l}\text { Okul müdürlerinin dağı̆tımcı liderlik davranışları ile } \\
\text { öğretmenlerin örgütsel bağıllıkları pozitif yönde ilişkilidir. }\end{array}$ & $\mathrm{r}=.73$ \\
\hline 11 & Bozkuş ve Gündüz (2016) & $\begin{array}{l}333 \text { ilkokul, } \\
\text { ortaokul ve } \\
\text { lise ögrretmeni }\end{array}$ & $\begin{array}{l}\text { Ruhsal liderlik } \\
\text { Örgütsel bağllık } \\
\text { Duygusal bağllık, Normatif bağll11k } \\
\text { Devam bağll1ığ } 1\end{array}$ & $\begin{array}{l}.94 \\
.58-.79 \text { (Uyarlama } \\
\text { yapilan } \\
\text { çalıșmadan rapor) } \\
\end{array}$ & $\begin{array}{l}\text { Korelasyonel } \\
\text { Yapisal eşitlik } \\
\text { modeli }\end{array}$ & $\begin{array}{l}\text { Ruhsal liderlik örgütsel bağll11ı̆ı pozitif olarak yordamaktadır. } \\
\text { Ruhsal liderlik duygusal bağllıı̆ı, devam bağllığını ve } \\
\text { normatif bağllıı̆ı pozitif yönde yordamaktadır. }\end{array}$ & $\begin{array}{l}\beta=.23 \\
\beta=.39, \beta=.27 \\
\beta=.37\end{array}$ \\
\hline 12 & Aytaç (2015) & $\begin{array}{l}402 \text { lise } \\
\text { ögretmeni }\end{array}$ & 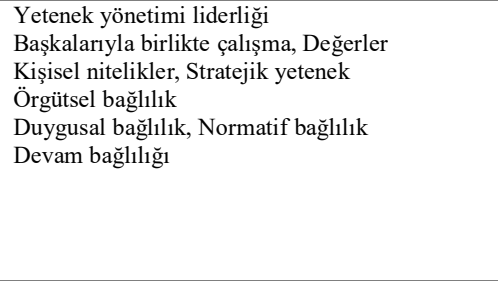 & .87 & $\begin{array}{l}\text { Korelasyon } \\
\text { Regresyon }\end{array}$ & 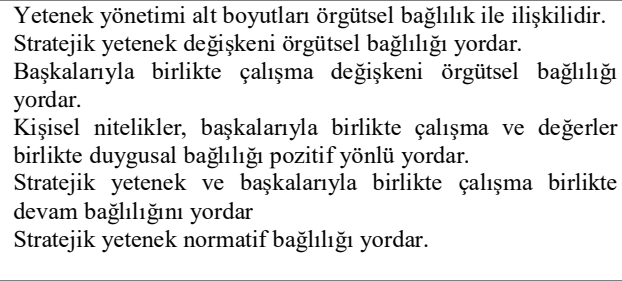 & $\begin{array}{l}r=.17-.91 \\
\beta=.53 \\
\beta=.40 \\
\left(R^{2}=.90\right) \\
\left(R^{2}=.12\right) \\
\beta=.86\end{array}$ \\
\hline 13 & Arabacı, Alanoğlu ve Doğan (2014) & $\begin{array}{l}217 \\
\text { ilköğretim ve } \\
\text { ortaöğretim } \\
\text { ögretmeni }\end{array}$ & 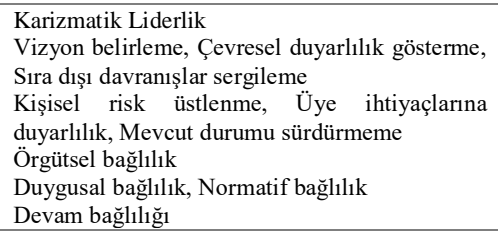 & .85 & $\begin{array}{l}\text { Tanımlayıcı } \\
\text { Korelasyon }\end{array}$ & 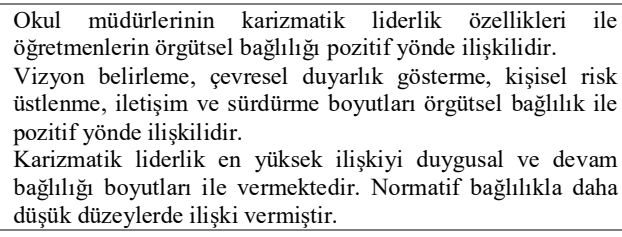 & $\begin{array}{l}\mathrm{r}=.19 \\
\mathrm{r}=.14-.20\end{array}$ \\
\hline
\end{tabular}


Okul Müdürü Liderliği ve Öğretmen Bağlllığı İlişsisi

\begin{tabular}{|c|c|c|c|c|c|c|c|}
\hline \multicolumn{8}{|c|}{ Ek 1. Devamı } \\
\hline 14 & Ayık, Yücel ve Savaş (2014) & $\begin{array}{l}267 \quad \text { ilkokul } \\
\text { öğretmeni }\end{array}$ & $\begin{array}{l}\text { Etik liderlik } \\
\text { Iletişimsel etik, iklimsel etik, karar vermede etik, } \\
\text { davrantşsal etik } \\
\text { Orgütsel bağll11k } \\
\text { Duygusal bağll1ı̆ı, devam bağlılığı, normatif } \\
\text { bağll11k }\end{array}$ & $\begin{array}{l}.98 \\
.92-96 \\
.91 \\
.76-83\end{array}$ & $\begin{array}{l}\text { Tanımlayıc1 } \\
\text { Korelasyon } \\
\text { Regresyon }\end{array}$ & 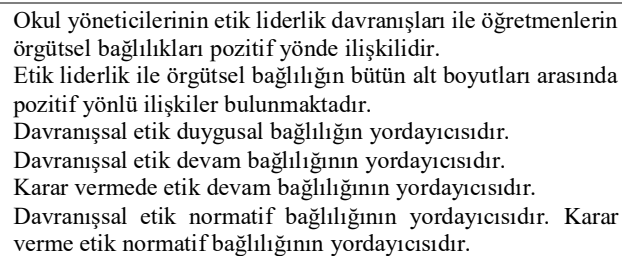 & $\begin{array}{l}\mathrm{r}=.51 \\
\mathrm{r}=.27-.51 \\
\beta=.55 \\
\beta=.90 \\
\beta=.29 \\
\beta=.59 \\
\beta=-.29\end{array}$ \\
\hline 15 & Uğurlu, Sincar ve Çınar (2013) & $\begin{array}{l}195 \\
\text { ortaöğretim } \\
\text { ögretmeni }\end{array}$ & $\begin{array}{l}\text { Etik liderlik } \\
\text { Örgütsel bağgll1k } \\
\text { Duygusal bağllık, normatif bağlllık ve devam } \\
\text { bağll1ı̆̆ı }\end{array}$ & $\begin{array}{l}.97 \\
.76 \\
\text { (orijinal } \\
\text { çalışmadan rapor) }\end{array}$ & $\begin{array}{l}\text { Tanımlayıc1 } \\
\text { Regresyon }\end{array}$ & $\begin{array}{l}\text { Etik liderlik davranılları ile örgütsel bağllıı pozitif yönde } \\
\text { iliskilidir ve etik liderlik yordayıcıdır. } \\
\text { Etik liderlik duygusal bağllığı ve normatif bağl1lı̆ı̆ yordar. }\end{array}$ & $\begin{array}{l}\left(\mathrm{R}^{2}=.058\right) \\
\left(\mathrm{R}^{2}=.037\right) \\
\left(\mathrm{R}^{2}=.057\right)\end{array}$ \\
\hline 16 & Uğurlu ve Üstüner (2011) & $\begin{array}{l}1112 \text { ilkokul, } \\
\text { ortaokul ve } \\
\text { lise ögrretmeni }\end{array}$ & $\begin{array}{l}\text { Etik liderlik } \\
\text { İletisimsel etik, iklimsel etik, karar vermede etik, } \\
\text { davranıssal etik } \\
\text { Orgütsel bağll11k } \\
\text { Duygusal bağll1k, devam bağll1ı̆̆, normatif } \\
\text { bağll11k }\end{array}$ & $\begin{array}{l}.98 \\
.89-.98 \\
.73 \\
.73-.86 \quad \text { (Orijinal } \\
\text { uyarlama sonucu } \\
\text { rapor edilmiş) }\end{array}$ & Regresyon & 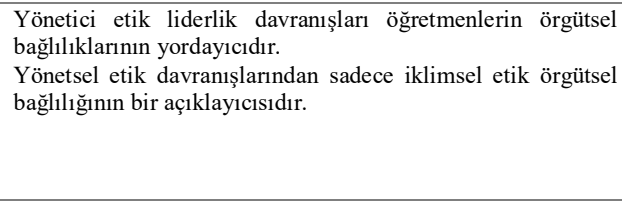 & $\begin{array}{l}\mathrm{R}^{2}=.14 \\
\beta=.21\end{array}$ \\
\hline 17 & $\begin{array}{l}\text { Madenoğlu, Uysal, Sarıer ve Banoğlu } \\
\text { (2014) }\end{array}$ & $\begin{array}{l}940 \text { lise } \\
\text { ögretmeni }\end{array}$ & $\begin{array}{l}\text { Etik liderlik } \\
\text { Iletişimsel etik, iklimsel etik, karar vermede etik, } \\
\text { davranıssal etik } \\
\text { Orgütsel bağlllık }\end{array}$ & .99 & Regresyon & $\begin{array}{l}\text { Okul müdürlerinin etik liderlik davranışlar öğretmenlerin } \\
\text { bağllıı̆ını yordamaktadır. }\end{array}$ & $\beta=.74$ \\
\hline 18 & Okçu (2014) & $\begin{array}{l}590 \\
\text { ortaöğretim } \\
\text { ögretmeni }\end{array}$ & $\begin{array}{l}\text { Etik liderlik } \\
\text { Hoşgörü, } \\
\text { demokrasi } \\
\text { Örgütsel bağlllık } \\
\text { Uyum, Özdeşleşme, İçselleştirme }\end{array}$ & $\begin{array}{l}.97 \\
.82-.94 \\
.91 \\
.82-.93\end{array}$ & $\begin{array}{l}\text { Korelasyon } \\
\text { Regresyon }\end{array}$ & 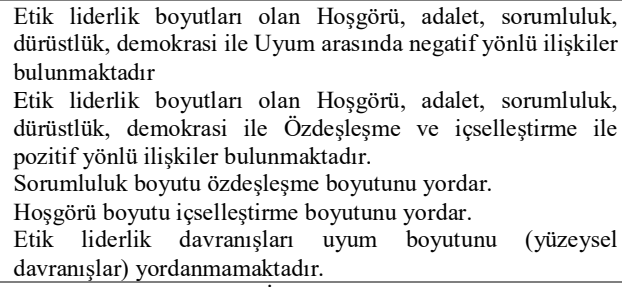 & $\begin{array}{l}r=-.12 / . .22 \\
r=.21 / .37 \\
\beta=.26 \\
\beta=.08\end{array}$ \\
\hline 19 & Buluç (2009) & $\begin{array}{l}250 \\
\text { ilköğretim } \\
\text { oğretmeni }\end{array}$ & 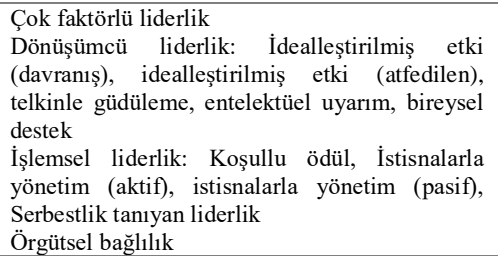 & $\begin{array}{l}.69 \\
.41-.81 \\
.93\end{array}$ & $\begin{array}{l}\text { Korelasyon } \\
\text { Regresyon }\end{array}$ & 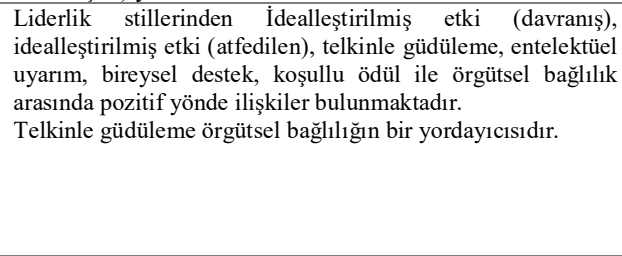 & $\mathrm{r}=.43-\mathrm{r}=.64$ \\
\hline
\end{tabular}


Cansoy ve Polatcan

\begin{tabular}{|c|c|c|c|c|c|c|c|}
\hline \multicolumn{8}{|c|}{ Ek 1. Devamı } \\
\hline 20 & Çetin ve Aydin (2012) & $\begin{array}{l}465 \\
\text { ortaöğretim } \\
\text { ögretmeni }\end{array}$ & 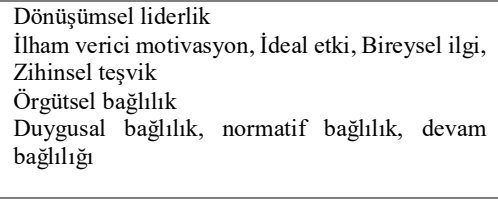 & .78 & $\begin{array}{l}\text { Tanımlayıcı } \\
\text { Korelasyon } \\
\text { Regresyon }\end{array}$ & 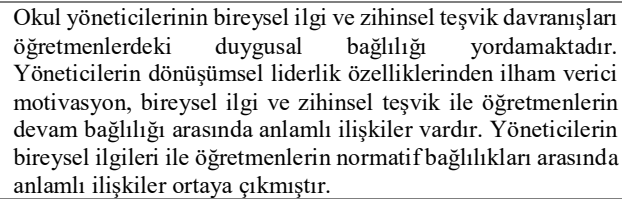 & $\mathrm{R}^{2}=30$ \\
\hline 21 & Kul ve Güçlü (2010) & $\begin{array}{l}291 \text { beden } \\
\text { eğitimi } \\
\text { öğretmeni }\end{array}$ & $\begin{array}{l}\text { Çok faktörlü liderlik } \\
\text { Dönüşümcü liderlik, İşlemsel liderlik } \\
\text { Örgütsel bağlll1k } \\
\text { Uyum, Özdeşleşme, İçselleş̧tirme }\end{array}$ & Rapor edilmemiş & $\begin{array}{l}\text { Tanımlayıcı } \\
\text { Korelasyon } \\
\text { Regresyon }\end{array}$ & 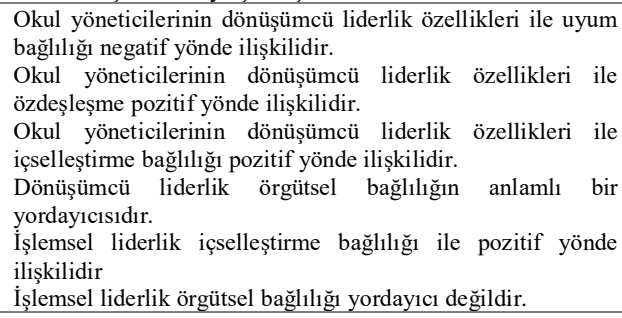 & $\begin{array}{l}r=-.34 \\
r=.51 \\
r=.80 \\
\beta=.39 \\
r=.72\end{array}$ \\
\hline 22 & Bektaş, Çoğaltay ve Sökmen (2014) & $\begin{array}{l}296 \\
\text { ilköğretim } \\
\text { öğretmeni }\end{array}$ & $\begin{array}{l}\text { Cook faktörlü liderlik } \\
\text { Dönüsüumcü liderlik, Sürdürümcü liderlik } \\
\text { Serbestlik tanıyan liderlik } \\
\text { Örrgütsel bağlll1k } \\
\text { Uyum, Özdeşleşme, İçselleştirme }\end{array}$ & $\begin{array}{l}.95 \\
.76-98 \\
.90 \\
.88-90\end{array}$ & $\begin{array}{l}\text { Tanımlayıcı } \\
\text { Korelasyon } \\
\text { Regresyon }\end{array}$ & 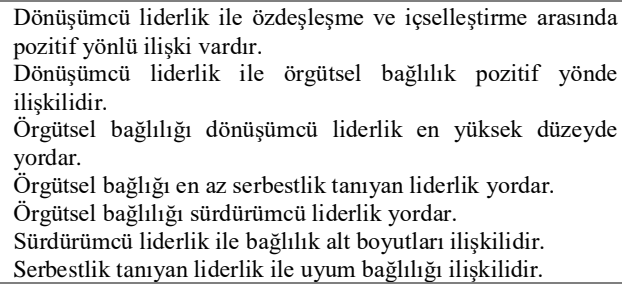 & $\begin{array}{l}\mathrm{r}=.67-\mathrm{r}=.50 \\
\mathrm{r}=.54 \\
\mathrm{R}^{2}=.30 \\
\mathrm{R}^{2}=.01 \\
\mathrm{R}^{2}=.15 \\
\mathrm{r}=.15-\mathrm{r}=.44 \\
\mathrm{r}=.43\end{array}$ \\
\hline 23 & Akan ve Yalçın (2015) & $\begin{array}{l}515 \text { ilkokul, } \\
\text { ortaokul ve } \\
\text { lise ögrretmeni }\end{array}$ & $\begin{array}{l}\text { Liderlik stilleri } \\
\text { Dönüşümcü liderlik, Sürdürümcü liderlik } \\
\text { Serbest bırakıcı liderlik } \\
\text { Orgütsel bağlllık } \\
\text { Uyum, Özdeşleşme, İ̧̧selleştirme }\end{array}$ & $\begin{array}{l}\text { Rapor edilmemiş } \\
.90 \\
.85-93\end{array}$ & $\begin{array}{l}\text { Tanımlayıcı } \\
\text { Korelasyon } \\
\text { Regresyon }\end{array}$ & 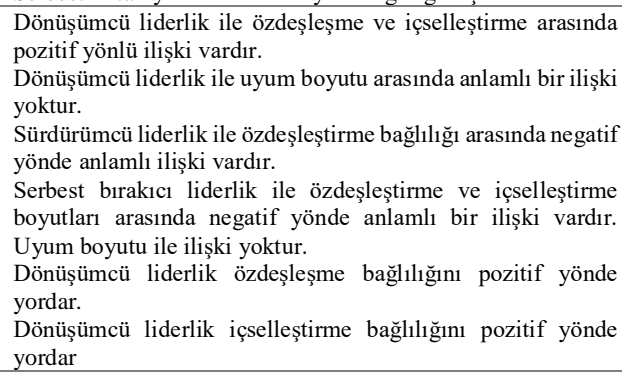 & $\begin{array}{l}\mathrm{r}=-.13 \\
\mathrm{r}=-.15, \mathrm{r}=-.19\end{array}$ \\
\hline
\end{tabular}


Cansoy, R. \& Polatcam, M. (2019). The Relationship Between School Principals' Leadership and Teachers' Organisational Commitment: A Systematic Review. Bartın University Journal of Faculty of Education, 8(1), 1-31.

\section{References}

Allen, N. J., \& Meyer, J. P. (1993). Organizational commitment: evidence of career stage effects? Journal of Business Research, 26(1), 49-61.

Anderman, E. M., Belzer, S. \& Smith, J. (1991). Teacher commitment and job satisfaction: The role of school culture and principal leadership. ERIC. Accessed on 05/06/2018 from https://files.eric.ed.gov/fulltext/ED375497.pdf.

Andrews, R. L., \& Soder, R. (1987). Principal leadership and student achievement. Educational Leadership, 44(6), 9-11.

Bass, B. M. (1990). From transactional to transformational leadership: Learning to share the vision. Organizational Dynamics, 18(3), 19-31.

Black, G. L. (2010). Correlational analysis of servant leadership and school climate. Catholic Education: A Journal of Inquiry and Practice, 13(4), 437-466.

Blase, J., \& Blase, J. (1999). Principals' instructional leadership and teacher development: Teachers' perspectives. Educational Administration Quarterly, 35(3), 349-378.

Brown, M., Trevino L., \& Harrison D. (2005). Ethical Leadership, a social learning perspective for construct development and testing. Organizational Behavior and Human Decision Processes, 97, 117-134.

Buchanan, B. (1974). Building organizational commitment: The socialization of managers in work organizations. Administrative Science Quarterly, 533-546.

Canrinus, E. T., Helms-Lorenz, M., Beijaard, D., Buitink, J., \& Hofman, A. (2012). Self-efficacy, job satisfaction, motivation and commitment: Exploring the relationships between indicators of teachers' professional identity. European Journal of Psychology of Education, 27(1), 115-132.

Cheng, Y.C. (1990). An investigation of antecedents of organizational commitment. Educational Research Journal, 5, 29-42.

Chew, J., \& Chan, C. C. (2008). Human resource practices, organizational commitment and intention to stay. International Journal of Manpower, 29(6), 503-522.

Choi, P. L., \& Tang, S. Y. F. (2009). Teacher commitment trends: Cases of Hong Kong teachers from 1997 to 2007. Teaching and Teacher Education, 25(5), 767-777.

Cowden, T., Cummings, G., \& Profetto-Mcgrath, J. (2011). Leadership practices and staff nurses' intent to stay: a systematic review. Journal of Nursing Management, 19(4), 461-477.

Cummings, G. G., MacGregor, T., Davey, M., Lee, H., Wong, C. A., Lo, E., ... \& Stafford, E. (2010). Leadership styles and outcome patterns for the nursing workforce and work environment: a systematic review. International Journal of Nursing Studies, 47(3), 363-385.

Day, C., \& Leithwood, K. (Eds.) (2007). Starting with what we know. In Successful principal leadership in times of change: An international perspective. Springer: Science \& Business Media.

Davies, E. B., Morriss, R., \& Glazebrook, C. (2014). Computer-delivered and web-based interventions to improve depression, anxiety, and psychological well-being of university students: a systematic review and metaanalysis. Journal of Medical Internet Research, 16(5), 18-39.

Dinham, S. (2005). Principal leadership for outstanding educational outcomes. Journal of Educational Administration, 43(4), 338-356.

EPPI-Centre (2006). EPPI-Centre methods for conducting systematic reviews. Accessed on 10/06/2018 from http://pblevaluation.pbworks.com/w/file/fetch/14976232/EPPI-Centre_Review_Methods_1.pdf.

Geijsel, F., Sleegers, P., Leithwood, K., \& Jantzi, D. (2003). Transformational leadership effects on teachers' commitment and effort toward school reform. Journal of Educational Administration, 41(3), 228-256.

Germain, B. P., \& Cummings, G. G. (2010). The influence of nursing leadership on nurse performance: a systematic literature review. Journal of Nursing Management, 18(4), 425-439. 
Gough, D. (2007). Weight of evidence: a framework for the appraisal of the quality and relevance of evidence. Research Papers in Education, 22(2), 213-228.

Griffith, J. (2004). Relation of principal transformational leadership to school staff job satisfaction, staff turnover, and school performance. Journal of Educational Administration, 42(3), 333-356.

Gupta, M. R. (2017). Organizational Commitment and Job Satisfaction Among School Teachers: A Comparative Study. Psychology in India, 5(1), 42-48.

Hallinger, P., \& Heck, R. H. (1996). Reassessing the principal's role in school effectiveness: A review of the empirical research. Educational Administration Quarterly, 32(1), 27-31.

Hallinger, P., Bickman, L., \& Davis, K. (1996). School context, principal leadership, and student reading achievement. The Elementary School Journal, 96(5), 527-549.

Hallinger, P., Hosseingholizadeh, R., Hashemi, N., \& Kouhsari, M. (2018). Do beliefs make a difference? Exploring how principal self-efficacy and instructional leadership impact teacher efficacy and commitment in Iran. Educational Management Administration \& Leadership, 46(5), 800-819.

Harris, A. (2004). Distributed leadership and school improvement: leading or misleading? Educational Management Administration \& Leadership, 32(1), 11-24.

Hart, D. R., \& Willower, D. J. (1994). Principals' organizational commitment and school environmental robustness. The Journal of Educational Research, 87(3), 174-179.

Heck, R. H., Larsen, T. J., \& Marcoulides, G. A. (1990). Instructional leadership and school achievement: Validation of a causal model. Educational Administration Quarterly, 26(2), 94-125.

Heck, R. H., \& Hallinger, P. (2009). Assessing the contribution of distributed leadership to school improvement and growth in math achievement. American Educational Research Journal, 46(3), 659-689.

Higgins, J. P., \& Green, S. (Eds.). (2011). Cochrane handbook for systematic reviews of interventions. John Wiley $\&$ Sons.

Hulpia, H., Devos, G., \& Van Keer, H. (2011). The relation between school leadership from a distributed perspective and teachers' organizational commitment: Examining the source of the leadership function. Educational Administration Quarterly, 47(5), 728-771.

Ibrahim, M. S., Ghavifekr, S., Ling, S., Siraj, S., \& Azeez, M. I. K. (2014). Can transformational leadership influence on teachers' commitment towards organization, teaching profession, and students learning? A quantitative analysis. Asia Pacific Education Review, 15(2), 177-190.

Jackson, T. A., Meyer, J. P., \& Wang, X. H. (2013). Leadership, commitment, and culture: A metaanalysis. Journal of Leadership \& Organizational Studies, 20(1), 84-106.

Karaçam, Z. (2014). Sistematik derleme metodolojisi: Sistematik derleme hazırlamak için bir rehber. Dokuz Eylül Üniversitesi Hemşirelik Fakültesi Elektronik Dergisi, 6(1), 26-33.

Kim, K. Y., Eisenberger, R., \& Baik, K. (2016). Perceived organizational support and affective organizational commitment: Moderating influence of perceived organizational competence. Journal of Organizational Behavior, 37(4), 558-583.

Leithwood, K., \& Jantzi, D. (1990). Transformational leadership: How principals can help reform school cultures. School Effectiveness and School Improvement, 1(4), 249-280.

Leithwood, K., \& Jantzi, D. (2000). The effects of transformational leadership on organizational conditions and student engagement with school. Journal of Educational Administration, 38(2), 112-129.

Leithwood, K. A., \& Riehl, C. (2003). What we know about successful school leadership. Philadelphia: Laboratuary Student Succes, Temple University. Accessed on 10/06/2018 from http://olms.cte.jhu.edu/olms2/data/ck/file/What_we_know_about_SchoolLeadership.pdf.

Leithwood, K., \& Jantzi, D. (2005). A review of transformational school leadership research 19962005. Leadership and Policy in Schools, 4(3), 177-199. 
Lunny, C., Brennan, S. E., McDonald, S., \& McKenzie, J. E. (2016). Evidence map of studies evaluating methods for conducting, interpreting and reporting overviews of systematic reviews of interventions: rationale and design. Systematic Reviews, 5(1), 1-8.

Mathieu, J. E., \& Zajac, D. M. (1990). A review and meta-analysis of the antecedents, correlates, and consequences of organizational commitment. Psychological Bulletin, 108(2), 171-194.

Mathieu, J. E., \& Farr, J. L. (1991). Further evidence for the discriminant validity of measures of organizational commitment, job involvement, and job satisfaction. Journal of Applied Psychology, 76(1), 127.

Marks, H. M., \& Printy, S. M. (2003). Principal leadership and school performance: An integration of transformational and instructional leadership. Educational Administration Quarterly, 39(3), 370-397.

Meyer, J. P., \& Allen, N. J. (1991). A three-component conceptualization of organizational commitment. Human Resource Management Review, 1(1), 61-89.

Meyer, J. P., Stanley, D. J., Herscovitch, L., \& Topolnytsky, L. (2002). Affective, continuance, and normative commitment to the organization: A meta-analysis of antecedents, correlates, and consequences. Journal of Vocational Behavior, 61(1), 20-52.

Morris, J.H., \& Sherman, J.D. (1981). Generalizability of an organizational commitment model. Academy of Management Journal, 24, 512-526.

Mowday, R. T., Steers, R. M., \& Porter, L. W. (1979). The measurement of organizational commitment. Journal of Vocational Behavior, 14(2), 224-247.

Murphy, J., \& Vriesenga, M. (2006). Research on school leadership preparation in the United States: An analysis. School Leadership and Management, 26(2), 183-195.

Nguni, S., Sleegers, P., \& Denessen, E. (2006). Transformational and transactional leadership effects on teachers' job satisfaction, organizational commitment, and organizational citizenship behavior in primary schools: The Tanzanian case. School Effectiveness and Sschool Improvement, 17(2), 145-177.

O'Reilly, C. A., \& Chatman, J. (1986). Organizational commitment and psychological attachment: The effects of compliance, identification, and internalization on prosocial behavior. Journal of Applied Psychology, 71(3), 492-503.

Reichers, A. E. (1985). A review and reconceptualization of organizational commitment. Academy of Management Review, 10(3), 465-476.

Ross, J. A., \& Gray, P. (2006). Transformational leadership and teacher commitment to organizational values: The mediating effects of collective teacher efficacy. School Effectiveness and School Improvement, 17(2), 179-199.

Porter, L. W., Steers, R. M., Mowday, R. T., \& Boulian, P. V. (1974). Organizational commitment, job satisfaction, and turnover among psychiatric technicians. Journal of Applied Psychology, 59(5), 603.

Silins, H. C. (1994). The relationship between transformational and transactional leadership and school improvement outcomes. School Effectiveness and School Improvement, 5(3), 272-298.

Spillane, J. P. (2003). Educational leadership. Educational Evaluation and Policy Analysis, 25(4), 343-346.

Steers, R. M. (1977). Antecedents and outcomes of organizational commitment. Administrative Science Quarterly, 46-56.

Sun, J. (2004). Understanding the impact of perceived principal leadership style on teacher commitment. International Studies in Educational Administration, 32(2), 18-31.

Tsui, K. T., \& Cheng, Y. C. (1999). School organizational health and teacher commitment: A contingency study with multi-level analysis. Educational Research and Evaluation, 5(3), 249-268.

Victor, L. (2008). Systematic reviewing. Social Research Update, 54(1), 1-4.

Waters, J. T., \& Marzano, R. J. (2006). School district leadership that works: The effect of superintendent leadership on student achievement. ERS Spectrum, (25)2, 1-2. 
Wiener, Y. (1982). Commitment in organizations: A normative view. Academy of Management Review, 7(3), 418428.

Williams, L. J., \& Anderson, S. E. (1991). Job satisfaction and organizational commitment as predictors of organizational citizenship and in-role behaviors. Journal of Management, 17(3), 601-617.

Yahaya, R., \& Ebrahim, F. (2016). Leadership styles and organizational commitment: literature review. Journal of Management Development, 35(2), 190-216.

Youngs, P., \& King, M. B. (2002). Principal leadership for professional development to build school capacity. Educational Administration Quarterly, 38(5), 643-670.

Yu, H., Leithwood, K., \& Jantzi, D. (2002). The effects of transformational leadership on teachers' commitment to change in Hong Kong. Journal of Educational Administration, 40(4), 368-389.

Yukl, G. (2012). Effective leadership behavior: What we know and what questions need more attention. The Academy of Management Perspectives, 26(4), 66-85.

\section{Reviewed Articles}

Akan, D. (2015). Okul yöneticilerinin liderlik stilleri ile öğretmenlerin örgütsel bağlılıkları arasındaki ilişkinin incelenmesi [Examining the relationship between school administrators' leadership styles and teachers' organisational commitment]. Eğitim Journal of Education and Humanities: Theory and Practice, 6(11), 123150.

Arabacı, İ. B. (2014). Okul müdürlerinin karizmatik liderlik özellikleri ile öğretmenlerin örgütsel bağlılıkları arasındaki ilişki [The relationship between school principals' charismatic leadership skills and teachers' organisational commitment]. Turkish Journal of Educational Studies, 1(1), 192-221.

Ayık, A., Yücel, E., \& Savaş, M. (2014). Öğretmenlerin örgütsel bağlılıklarının yordayıcısı olarak okul yöneticilerinin etik liderlik davranışları [School administrators' ethical leadership behaviours as predictors of teachers' organisational commitment]. Dumlupinar University Journal of Social Sciences, (42), 27-36.

Aytaç, T. (2015). The relationship between teachers' perception about school managers' talent management leadership and the level of organizational commitment. Eurasian Journal of Educational Research, 59, 165179.

Bektaş, F., Çoğaltay, N., \& Sökmen, Y. (2014). Öğretmen algılarına göre okul müdürlerinin liderlik stillerinin örgütsel bağl1lık üzerindeki rolü [The role of school principals' leadership styles on organisational commitment based on teacher perceptions]. International Journal of Turkish Education Sciences, 2014(3), 122-130.

Bozkuş, K., \& Gündüz, Y. (2016). Ruhsal liderlik ile örgütsel bağlılık arasındaki ilişkinin modellenmesi [Modelling the relationship between spiritual leadership and organisational commitment]. Kastamonu Education Journal, 24(1), 405-420.

Buluç, B. (2009). Sınıf öğretmenlerinin algılarına göre okul müdürlerinin liderlik stilleri ile örgütsel bağlılık arasındaki ilişki [The relationship between school principals' leadership styles and organisational commitment based on elementary school teachers' perceptions]. Educational Administration: Theory and Practice, 57(57), 5-34.

Cerit, Y. (2010). The effects of servant leadership on teachers' organizational commitment in primary schools in Turkey. International Journal of Leadership in Education, 13(3), 301-317.

Çağrıcı, D. Ç., \& Savaş, A. C. (2016). İlkokul ve ortaokul müdürlerinin değişim liderliği davranışları ile öğretmenlerin örgütsel bağlılıkları arasındaki ilişki [The relationship between elementary and middle school principals' leadership behaviours and teachers' organisational commitment]. Journal of Human Sciences, 13(1), 621-631.

Çetin, Ö., \& Aydın, B. (2012). Ortaöğretim okulu yöneticilerinin dönüşümsel liderlik özelliklerinin öğretmenlerin örgütsel bağlılıklarına etkisi [The effect of high school administrators' transformational leadership behaviours 
on teachers' organisational commitment]. Mustafa Kemal University Journal of Social Sciences, 9(19), 331342.

Çokluk, Ö., \& Yılmaz, K. (2010). The relationship between leadership behavior and organizational commitment in Turkish primary schools. Bilig, 54, 75-92.

Doğan, Ü., \& Aslan, H. (2016). Özel eğitim kurumlarında çalışan müdürlerin hizmetkâr liderlik davranışları ile öğretmenlerin örgütsel adanmışlık düzeyleri arasındaki ilişki [The relationship between servant leadership behaviours of principals working in special education centres and teachers' organisational commitment]. Ondokuz Mayıs University Journal of Education, 35(2), 51-68.

Erdoğan, Ş., \& Kolamaz, C. (2011). Destekleyici ve geliştirici liderlik özellikleri ile örgütsel bağl1lık arasındaki ilişki [The relationship between supportive and developing leadership characteristics and organisational commitment]. The Journal of Turkish Educational Sciences, 9(2), 313-342.

Kul, M., \& Güçlü, M. (2010). Okul yöneticilerinin liderlik stilleri ile beden eğitimi öğretmenlerinin örgütsel bağlılıkları arasındaki ilişki [The relationship between school principals' leadership styles and physical education teachers' organisational commitment]. International Journal of Human Sciences, 7(2), 1021-1038.

Madenoğlu, C., Uysal, Ş., Sarıer, Y., \& Banoğlu, K. (2014). Okul müdürlerinin etik liderlik davranışları ile öğretmenlerin iş doyumlarının örgütsel bağlılıkla ilişkisi [The relationship of school principals' ethical leadership behaviours and teachers' job satisfaction with organisational commitment]. Educational Administration: Theory and Practice, 20(1), 47-69.

Okçu, V. (2014). Ortaöğretim okulu yöneticilerinin etik liderlik davranışları ile öğretmenlerin örgütsel bağlılıkları arasındaki ilişki [The relationship between high school administrators' ethical leadership behaviours and teachers' organisational commitment Educational Administration: Theory and Practice, 20(4), 501-524.

Teyfur, M. (2015). Ortaokul yöneticilerinin kültürel liderlik rollerini gerçekleştirme düzeyleri ile öğretmenlerin örgütsel bağlılığı arasındaki ilişki (Erzurum il örneği) [The relationship between high school administrators' levels of achieving cultural leadership roles and teachers organisational commitment (Case of Erzurum province)]. Journal of Human Sciences, 12(2), 1002-1025.

Uğurlu, C. T., Sincar, M., \& Çınar, K. (2013). Ortaöğretim okulu öğretmenlerinin örgütsel bağl1lık düzeylerine yöneticilerinin etik liderlik davranışlarının etkisi [The effect of administrators' ethical leadership behaviours on high school teachers' organisational commitment]. Erzincan University Journal of Education, 15(1), 266281.

Uğurlu, C. T., \& Üstüner, M. (2011). Öğretmenlerin örgütsel bağl1lık düzeylerine yöneticilerinin etik liderlik ve örgütsel adalet davranışlarının etkisi [The effect of administrators' ethical leadership and organisational justice behaviours on teachers' organisational commitment]. Hacettepe University Journal of Educationi, 41, 434-448.

Uslu, B., \& Beycioğlu, K. (2013). İlköğretim okulu öğretmenlerinin örgütsel bağlılıkları ile müdürlerin paylaşılan liderlik rolleri arasındaki ilişki [The relationship between elementary school teachers' organisational commitment and principals' shared leadership roles]. Ondokuz Mayıs University Journal of Education, 32(2), 323-345.

Uygur, M., \& Yıldırım, A. (2011). İlköğretim okulu yöneticilerinin kültürel liderlik rolleri ile öğretmenlerin örgütsel bağlılı̆̆ arasındaki ilişki [The relationship between elementary school administrators' cultural leadership roles and teachers' organisational commitment]. The Journal of The Industrial Arts Education Faculty of Gazi University, 27, 72-81.

Yaman, E., \& Ezer, Ö. (2015). Öğretmen algılarına göre ortaokul müdürlerinin öğretimsel liderlik davranışları ile öğretmenlerin örgütsel bağlılıkları arasındaki ilişki [The relationship between middle school principals' instructional leadership behaviours and teachers' organisational commitment based on teacher perceptions]. Journal of Bayburt Education Faculty, 10(1), 39-54.

Yetim, Z. (2016). İlköğretim kurumlarında dağıtımcı liderlik ile örgütsel bağlılık arasındaki ilişki (Seydikemer örneği) [The relationship between distributive leadership and organisational commitment in elementary schools (Case of Seydikemer district]. Journal of International Social Research, 9(43), 1565-1572. 